\title{
The Demand for Healthcare Regulation: The Effect of Political Spending on Occupational Licensing Laws
}

\section{Benjamin J. McMichael}

University of Alabama - School of Law, bmcmichael@law.ua.edu

\section{Recommended Citation}

Benjamin J. McMichael, The Demand for Healthcare Regulation: The Effect of Political Spending on Occupational Licensing Laws, (2015).

Available at: https://scholarship.law.ua.edu/fac_working_papers/604 
The Demand for Healthcare Regulation:

The Effect of Political Spending on Occupational Licensing Laws

\author{
Benjamin J. McMichael*
}

Running Head: Political Spending and Licensing Laws

Affiliation: Postdoctoral Scholar, Owen Graduate School of Management, Vanderbilt University. 401 21st Avenue South, Nashville, TN, USA, 37203. Phone: 615-875-8835. Email:

benjamin.j.mcmichael@vanderbilt.edu.

JEL Codes: I18, K23

*I wish to thank R. Lawrence Van Horn, W. Kip Viscusi, Peter Buerhaus, and James Blumstein for their guidance in developing this paper. I also wish to thank the participants of the Wake Forest University Economics Department Workshop Series for helpful comments on an earlier draft. 


\begin{abstract}
Using data on political spending in state elections, this study considers the role of political contributions by healthcare professional interest groups in states' decisions to enact occupational licensing laws. These laws govern how different professions may operate in healthcare markets, and while they ostensibly exist to protect consumers, licensing laws can also insulate professionals from competition in healthcare markets. Higher political spending by physician interest groups increases the probability that a state maintains licensing laws restricting the practices of nurse practitioners (NPs) and physician assistants (PAs). Conversely, increased spending by hospital interest groups increases the probability that a state allows NPs and PAs to practice with more autonomy. Nurse groups, which include groups affiliated with NPs, have a smaller effect on licensing laws. And non-physician groups, which include groups affiliated with PAs, have almost no effect on licensing laws. These results are consistent with the investment theory of political spending.
\end{abstract}




\section{Introduction}

In 2015, the Supreme Court of the United States abrogated the antitrust immunity previously enjoyed by state licensing boards. In North Carolina State Board of Dental Examiners v. Federal Trade Commission (NC Board), the Court ruled that a state dental board was not entitled to antitrust immunity when it attempted to ban the sale of tooth-whitening products by non-dentists. Licensing boards, such as the dental board in NC Board, administer occupational licensing laws which govern how members of a profession may practice. As the Supreme Court noted, these laws are designed to promote public health and safety but may be misused to insulate professional groups from competition. On a similar note, the White House has suggested that licensing laws may unnecessarily restrict competition in a variety of markets (Office of Economic Policy 2015). The NC Board decision substantially undermined the ability of professional groups to use the regulatory power wielded by state licensing boards to restrict competition in the services provided by their members, so professional groups will have to turn to other means of promoting their interests through occupational licensing laws.

This study explores an alternative mechanism of rent seeking by industry and professional groups - political contributions. It considers the role of political spending by these groups in states' decisions to adopt restrictive occupational licensing laws. While the Court's decision in NC Board limits the ability of industry and professional groups to use licensing boards to promote their interests, they remain free to make campaign contributions to persuade state legislatures to enact statutes favorable to their interests. Specifically, this study examines how political spending by healthcare interest groups influences states' decisions to adopt occupational licensing laws governing nurse practitioners (NPs) and physician assistants (PAs). The analysis focuses on physician supervision laws, which govern the degree of physician 
involvement in NP and PA practices. These laws are generally statutory and, thus, not subject to manipulation by state licensing boards in the way the law in NC Board was. Physician supervision laws, which vary substantially across states, can impede the ability of NPs and PAs to satisfy the demand for healthcare, protect physicians from competition from NPs and PAs in healthcare markets, and effect a monetary transfer from NPs and PAs to physicians (see, e.g., Dueker et al. 2005; Kleiner et al. 2016).

NPs and PAs provide many of the same services as physicians, and clinical evidence has demonstrated that, within their knowledge and training, NPs and PAs can safely and competently care for patients (Newhouse et al. 2011; Laurant et al. 2009; Letz et al. 2004; Mundinger et al. 2000; Brown and Grimes 1995). A number of national organizations, including the Institute of Medicine (IOM), the National Governors Association (NGA), and the Federal Trade Commission (FTC), have noted that states can increase access to healthcare, lower costs, and improve their healthcare systems by allowing NPs and PAs to practice to the full extent of their knowledge and training (IOM 2011; NGA 2012, 2014; Gilman and Koslov 2014). The IOM and FTC have also suggested that the licensing laws governing NPs and PAs are driven more by politics than by economic, scientific, or clinical evidence (IOM 2011; Gilman and Koslov 2014).

Consistent with the IOM and FTC evaluations and Stigler's (1971) hypothesis that occupations with political power will seek favorable laws from the state, states may be responsive to political spending by healthcare interest groups. If states are responsive to political spending, physicians have an incentive to protect their market power by spending money to prevent the enactment of licensing laws reducing physician supervision requirements for NPs and PAs, while NPs and PAs have an incentive to spend money promoting laws granting them more autonomy. On the other hand, Ansolabehere et al. (2003) posit that political spending more 
closely resembles a typical consumption good. As such, groups simply spend more on politics as their incomes increase, and politicians do not reward increased spending with favorable policies.

To test whether states maintain restrictive licensing laws in response to political spending by industry and professional interest groups, I use a dataset of state political campaign contributions to analyze the degree to which political spending by different healthcare interest groups affects physician supervision laws for NPs and PAs. In general, the evidence demonstrates that increased political spending by physician interest groups decreases the probability that states allow NPs and PAs to practice with more autonomy, i.e., less physician supervision. Additionally, greater spending by interest groups associated with hospitals, which generally support greater autonomy for NPs and PAs, increases the probability that NPs and PAs can practice with less physician oversight. Interestingly, spending by physician groups and hospital groups has a much larger impact on NP and PA licensing laws than spending by groups related directly to the interests of NPs and PAs. These results are consistent with a rent-seeking battle over licensing laws between physician groups and hospital groups.

This study is the first to quantify the effects of political spending on occupational licensing laws, and it speaks to the growing debate over the effect of healthcare workforce regulation on the American healthcare system. Prior work on NPs, PAs, and their effect on the healthcare system has argued that the occupational licensing laws governing NPs and PAs stem from the idiosyncrasies of the political system (see Stange 2014), but the results presented here demonstrate that healthcare providers themselves can play an important role in how states regulate the healthcare workforce. This study also contributes to the campaign finance literature by providing empirical evidence suggesting that, consistent with the investment theory of political spending, such spending influences specific policy outcomes. 


\section{NPs, PAs, and the Laws That Govern Them}

\section{NP and PA Occupational Licensing Laws}

The NP and PA professions both emerged in the 1960s. Although their educations are different, both NPs and PAs typically complete between 1.5 and 3 years of training beyond the undergraduate level. Both professions can order and interpret tests, diagnose and treat patients, and write prescriptions. And both function similarly to physicians in a variety of settings. NPs and PAs currently outnumber family and general practice physicians, and many communities receive primary care services principally from NPs and PAs (Auerbach 2012; Stange 2014). However, NPs and PAs do not deliver care equally in all communities because occupational licensing laws vary substantially across states. Physician supervision laws represent some of the most salient restrictions on how NPs and PAs provide care, as they directly impact how NPs and PAs are able to interact with and treat patients, restrict the ability of NPs and PAs to provide care in convenient locations, and result in less income for NPs and PAs (Kleiner et al. 2016).

Table 1 provides a comprehensive overview of the changes in physician supervision laws for NPs and PAs from 1999 through 2013. Three basic physician supervision (sometimes called “collaboration") requirements exist for NPs. Complete supervision laws require that an NP practice only under the supervision of a physician. Prescription supervision laws allow NPs to practice without physician oversight but require NPs to have a supervisory relationship with a physician in order to prescribe medications to patients. Finally, at the highest level of autonomy, some states allow NPs to practice independently of physicians.

While no state allows PAs to practice independently, three basic types of supervision laws govern PAs. At the lowest level of autonomy, onsite supervision laws require that a physician be on the premises or within a certain distance, e.g., 30 miles, in order for a PA to treat 
patients. At the highest level of autonomy, remote supervision laws allow PAs to practice at remote sites with onsite physician visits required no more than monthly. Finally, quasi-remote supervision laws allow a PA to practice at a remote site but impose requirements that prevent the PA from practicing a significant distance from her supervising physician on a regular basis. Examples of these requirements include rules mandating that the supervising physician and PA be in direct contact at least semi-weekly and that the supervising physician practice at the same site as the PA for a certain percentage of the PA's practice time.

\section{Prior Research on NPs, PAs, and Occupational Licensing Laws}

Prior work on occupational licensing laws in the healthcare industry (and other industries) has focused on the effects, not the determinants, of those laws. For example, Shephard (1978) and Kleiner and Kudrle (2000) find that licensing laws increase the earnings of dentists. Adams, Ekelund, and Jackson (2003), Timmons and Thornton (2008), and Thornton and Timmons (2013) find that licensing laws increase the earnings of midwives, radiologic technologists, and massage therapists, respectively. Dueker et al. (2005) and Perry (2009) consider the effects of NP and PA licensing laws on the wages of NPs, PAs, and physicians, but find mixed evidence on the effects of these laws on earnings. Later work on the occupational licensing laws governing NPs and PAs examines the effects of these laws on the market for healthcare services. For example, Kleiner et al. (2016) find that, when state laws allow NPs to perform more services without physician supervision, the price of a common medical examination decreases. Stange (2014) finds that an increase in NP and PA supply has only small effects on the office-based healthcare market but that healthcare utilization is more responsive to the supply of NPs and PAs in states that maintain less restrictive licensing laws.

These studies elucidate the effects of licensing laws on providers and healthcare markets, 
but they do not examine the determinants of the laws themselves. In explaining the existence of different laws, most studies appeal to the idiosyncrasies of the political system as the reason states regulate NPs and PAs differently (see, e.g., Stange 2014) or attempt to confirm the exogeneity of healthcare licensing laws by regressing the existence of a law on economic and limited political factors (see, e.g., Traczynski and Udalova 2014). Stange (2014) notes that changes in political power among professional groups could confound studies investigating the effects of licensing laws on different healthcare outcomes. This study is the first to provide evidence on the missing link between political spending and licensing laws.

\section{Campaign Finance and Political Behavior}

Conventional wisdom suggests that money plays a substantial role in politics and affects policy outcomes. However, most studies in the existing empirical literature on political spending do not support the conventional wisdom (see Wolton 2016). As Ansolabehere et al. (2003) note, the majority of these studies focus on legislative voting patterns and find no link between contributions and votes. Ansolabehere et al. (2003) advance a consumption theory of political spending and posit that most campaign contributions are motivated by their consumption value as opposed to any expectation of return benefits. This suggests political spending has little impact on actual policy outcomes. In contrast, the investment theory posits that individuals, firms, and interest groups demand regulation that benefits them from the suppliers of regulation-legislatures and agencies (Stigler 1971; Peltzman 1976). In return, interest groups offer campaign contributions or other benefits to legislators.

Despite the development of the theory of interest groups and campaign contributions (see, e.g., Becker 1983; Grossman and Helpman 1994; Baron 2001; Persico 2015), relatively little empirical work has focused on linking groups and spending to specific policy outcomes. A 
number of studies have considered the effect of campaign contributions on legislative voting patterns (see Ansolabehere et al. 2003), but De Figueiredo and Edwards (2007) note that this literature fails to link political spending directly to the dependent variable of interest: policy outcomes. Exceptions to the dearth of empirical research on the effect of spending on state lawmaking include De Figueiredo and Edwards (2007) and Werner and Coleman (2015).

Occupational licensing laws provide a context uniquely well suited to studying the effects of political spending. Because these laws are of low salience to the public but high salience to those governed by them, concentrated interests (such as physicians, NPs, PAs, and hospitals) are likely to have a greater effect on states' decisions to pass these laws (see Hall and Wayman 1990; Feldstein 2011). When evaluating the effect of political spending on licensing laws, I focus on four professional groups - physicians, hospitals, nurses (which include NPs), and nonphysician practitioners (which include PAs) — and consider the roles of these groups in two general frameworks. Consistent with Becker's (1983) approach, the primary analysis considers the effect of per capita spending by different interest groups on the probability that a state enacts a licensing law requiring less physician oversight of NPs or PAs. As an extension of the main analysis, and consistent with Baron's (2001) model, I consider relative spending by different groups with different preferences on licensing laws (see De Figueiredo and Edwards 2007).

\section{Data}

State Laws

Information on the physician supervision laws in Table 1 comes directly from regulatory and statutory language. Coding all of the relevant laws based on the actual statutory and regulatory language facilitates consistent interpretation of those laws. Each state is coded as having one of the three licensing laws for NPs and PAs in each year. States listed in the top row 
of panels $\mathrm{A}$ and $\mathrm{B}$ in Table 1 did not change their laws during the study period. The second row of each panel lists states that changed their laws from one category to another. States that changed their laws multiple times during the study period are listed once for each change.

My analysis is limited to post-1998 for two reasons. First, the Balanced Budget Act of 1997 authorized direct reimbursement through Medicare for the services of NPs and PAs beginning in $1998 .{ }^{1}$ After 1998 , many private insurance companies followed suit in directly reimbursing NPs and PAs, so these professionals gained a greater interest in laws granting them more autonomy. Second, as noted below, data on political spending is not available early enough in the 1990s to calculate the relevant measures of political spending. For these reasons, my analysis focuses on the time period between 1999 and 2013.

\section{Political Spending}

Information on the political spending of different interest groups comes from the National Institute on Money in State Politics. These data were collected from required disclosures made by interest group contributors for all state primary and general elections. The data include all political contributions made by interest groups to candidates for statewide office, legislative office, and the highest court in the state, as well as all contributions to political parties. The data represent the universe of all state elections from 2000 forward, but information on elections into the mid-1990s is available in almost all instances. The data do not include expenditures by interest groups on independent political spending or lobbying over the relevant time period, but as noted by De Figueiredo and Edwards (2007) and Ansolabehere et al. (2002), political contribution data are good proxies for all nonmarket activity of interested parties, including lobbying and independent political spending. Wolton (2016) explains that the absence of these other types of spending may result — in certain circumstances - in an underestimate of the effect 
of spending on policy outcomes. Thus, the results reported here could represent a "floor" on the effect of political spending.

For each contribution, the Institute assigns an economic interest code based on the nature or purpose of the group making the contribution. I focus on contributions attributable to four general groups: physicians, hospitals, nurses, and non-physician practitioners. It is not possible to discern the purpose of specific contributions, so the amount of money spent in a given state and year represents the total political spending of an interest group as opposed to a group's spending on any given issue. ${ }^{2}$ While it is generally possible to discern the recipient of each contribution, the analysis here is not limited to interest group contributions to only members of specific legislative committees or in any other way. As Wolton (2016) notes, the inner workings of legislatures, such as what bills are brought up for a vote, are not exogeneous. Thus, limiting my analysis to anything more specific than political contributions by the four types of interest groups listed above would risk introducing endogeneity bias and imposing arbitrary restrictions on the workings of legislatures. For example, a key legislator on the committee responsible for licensing laws may "owe a favor" to a legislator who has no connection to that committee. Ignoring this second legislator could bias the results of my analysis.

The physician category used in my analysis includes, as defined by the National Institute on Money in State Politics, spending by interest groups related to physicians generally and groups related to specialist physicians. Similarly, the hospital category includes spending by groups related to hospitals and other healthcare institutions. The Institute's "nurse" category includes both NP groups and nurse groups more generally. However, in almost all instances, the primary source of support for greater NP autonomy is nurse organizations. Likewise, the category "non-physician health practitioners" is not unique to PAs; however, PA groups, along 
with physical therapist groups, dominate this category of spending. ${ }^{3}$ For both the nurse and nonphysician categories, it is not possible to unambiguously disaggregate the spending by different groups in these categories to isolate NP- or PA-specific groups. ${ }^{4}$

For each of these four professional/industry groups, I define a group's "clout" in a given state and year as the sum of political spending by interest groups connected with that profession per 1,000 state residents. Table 2 reports summary statistics for the clout of different interest groups. On average, per capita spending by physician groups and hospital groups is at least an order of magnitude greater than spending by nurse groups and non-physician practitioner groups. Figure 1 provides an overview of spending by the four groups over time. As in Table 2, hospital and physician spending outpace spending by the nurse and non-physician groups. For all groups, more spending occurs in election years — even years in most states — but the average level of spending has remained fairly stable over time.

As a number of researchers, including Snyder (1992) and De Figueiredo and Edwards (2007), have noted, politicians prefer to avoid the appearance of selling their votes. Therefore, the contributions of any given group are likely not rewarded immediately, but politicians may promote the interests of contributing groups over time. To account for this long-term effect, I calculate the two-year, three-year, and four-year totals of political clout. In general, I expect that the four-year total will best capture the effect of political clout since this time period includes at least one election in most state legislatures and generally includes two elections in the lower houses of state legislatures. All of the clout variables exhibit substantial right skews, so I calculate the natural logarithm of the two-, three-, and four-year totals of clout for use in the main analysis. Before doing so, I add one to the total spending of each group in each state-year. 
State Political, Legal, and Demographic Characteristics

Information on the percentage of each state's population covered by private health insurance, Medicare, Medicaid, and other health insurance programs comes from the United States Census Bureau. Variables for median income, population density, and the percentage of the population that identifies as black also come from data compiled by the Census Bureau. Information on the party of state governors comes from the Indiana State University Center for Governmental Services. Prior work has demonstrated that states with democratic governors are more likely to have laws that grant NPs and PAs more autonomy (Perry 2009), ${ }^{5}$ so I include the status of the governorship as a control variable. I also obtained information on the partisan control of state legislatures from the National Conference of State Legislatures to better control for state political environments.

Finally, I obtained information on state tort reforms from the Database of State Tort Law Reforms (DSTLR 5th) compiled by Avraham (2014). Medical malpractice law (and the deterrence it exerts on healthcare providers) represents an important parallel regulatory mechanism to licensing laws (see, e.g., Avraham and Schanzenbach 2015). Because of their role in regulating providers, I control for what the literature regards as the three major tort reforms: noneconomic damages caps, collateral source rule reform, and joint and several liability reform (see, e.g., Avraham and Schanzenbach 2010).

\section{Empirical Approach and Specification}

To examine the effects of political campaign contributions on state licensing law outcomes, I estimate linear probability models with the following general specification:

$$
\begin{aligned}
L_{s t}= & \alpha+\beta_{1} \log (\text { Nurse clout })_{s t}+\beta_{2} \log (\text { Non }- \text { physician clout })_{s t}+ \\
& \beta_{3} \log (\text { Physician clout })_{s t}+\beta_{4} \log (\text { Hospital clout })_{s t}+ \\
& (\text { Torts })_{s t}^{\prime} \delta_{1}+(\text { Insurance })_{s t}^{\prime} \delta_{2}+(\text { Demographics })_{s t}^{\prime} \delta_{3}+\theta_{s}+\theta_{t}+\varepsilon_{s t} .
\end{aligned}
$$


$L_{s t}$ is an indicator that equals one if a specific licensing law applies in state $s$ in year $t$. The first four variables on the right-hand side correspond to the clout of professional groups, while the rest of the variables control for state characteristics, voter preferences, alternative regulatory mechanisms, and state and time fixed effects. Throughout the analysis, separate models include three different temporal measures of political clout. First, I estimate models with the natural logarithm of each interest group's clout for the two years immediately preceding a given year. Next, I include the natural logarithm of each group's clout for the previous three and four years. I include both nurse clout and non-physician clout in the models for NP supervision laws and PA supervision laws. ${ }^{6}$ In general, the models including four-year measures of clout are the preferred specifications because they best capture the influence of professional groups as discussed above.

Torts $_{s t}$ is a vector of three indicator variables for whether state $s$ had enacted a noneconomic damages cap, collateral source rule reform, and joint and several liability reform in year $t$. Insurance $s t$ is a vector that includes the percentage of the state population covered by private insurance, the percentage covered by a state Medicaid program, and the percentage covered by Medicare. The Demographics $s$ vector includes indicators for whether the state had a democratic governor, whether the state legislature was controlled by Republicans, and whether the state legislature was controlled by Democrats - the omitted category for state legislatures is split control. This vector also includes the population density of the state, the natural logarithm of the median income for the state, and the percentage of a state's population that identifies as black. Vectors of state, $\theta_{s}$, and time, $\theta_{t}$, fixed effects control for fixed, unobserved determinants of licensing laws across states and over time.

The parameters of interest, $\beta_{1}, \beta_{2}, \beta_{3}$, and $\beta_{4}$, represent the change in the probability of a state adopting a given licensing law associated with an increase in the clout of different interest 
groups. Throughout the primary analysis, I estimate linear probability models, and standard errors are clustered at the state level. To confirm the robustness of the linear probability model results, I later estimate a series of rank ordered logit models.

\section{Results for the Effect of Political Clout on State Occupational Licensing Laws Results for NP Licensing Laws}

The first three columns of Table 3 report results from linear probability models with an indicator that equals one when a state allows independent NP practice in a given year as the dependent variable - full results are reported in Table A3 in the online appendix. All three columns include the same control variables but include different measures of political clout. Column (1) reports coefficient estimates for the logarithm of the two-year total of interest group clout, column (2) reports estimates for the three-year total, and column (3) reports the preferred specification with the four-year total of interest group clout. Across all three specifications, increases in nurse, physician, and hospital clout have the expected effects. Non-physician clout does not have a statistically significant effect in any specification. Focusing on the preferred specification in column (3), nurse, physician, and hospital clout have statistically significant effects on whether a state allows independent NP practice. The probability that a state allows NP independence increases by 0.12 percentage points when nurse clout increases by $10 \%$, decreases by 0.96 percentage points when physician clout increases by $10 \%$, and increases by 0.78 percentage points when hospital clout increases by $10 \%$. The effects of physician and hospital clout are 8 and 6.5 times larger, respectively, in magnitude than the effect of nurse clout, suggesting that physician and hospital groups play more important roles in determining whether a state allows NPs to practice independently than nurse groups. ${ }^{7}$

The last three columns of Table 3 report results from linear probability models with an 
indicator that equals one when a state allows independent NP practice or requires physician supervision of NPs when NPs prescribe medications (i.e., the two less restrictive categories of physician supervision laws) as the dependent variable. Again, non-physician clout never has a statistically significant effect. The remaining three measures of clout continue to have their expected signs, but only physician clout and nurse clout have statistically significant effects in the preferred specification in column (6). Physician clout has a larger effect on the probability that NPs are able to practice with less supervision than does nurse clout, as a $10 \%$ increase in physician clout decreases the probability NPs can practice with less physician supervision by 0.92 percentage points, while a $10 \%$ increase in nurse clout increases this probability by only 0.22 percentage points. The lack of a statistically significant effect for hospital clout suggests that hospitals may be more interested in pursuing NP independence than increased NP autonomy more generally. This is not surprising, as hospitals enjoy a substantial benefit from completely independent NPs—-hospitals no longer need to pay physicians to supervise their employed NPs. This benefit only inures to hospitals when NPs become completely independent.

Overall, physicians and hospitals wield relatively more influence over whether a state allows NPs to practice with more autonomy than nurses do. While the estimated effects are not obviously large in magnitude, they represent meaningful changes in the probability states allow NPs to practice with less oversight. For example, in 2013, 19 of 51 jurisdictions allowed NPs to practice independently. Using 0.4 as a rough probability of NP independence, a $10 \%$ increase in physician clout decreases this probability by $2.5 \%$, and a doubling of physician clout decreases this probability by $25 \%$ based on the estimated effects in column (3) of Table 3 . In a state with the median population (about 4.5 million), physicians could more than double the national average of their clout by collectively contributing the salary of an average physician $(\$ 180,000)$. 


\section{Results for PA Licensing Laws}

Table 4 reports the results from six linear probability models estimating the effect of political clout on the probability a state allows PAs to practice with less physician involvementfull results are reported in Table A4. The dependent variable in columns (1) - (3) is an indicator for whether PAs can practice remotely, and the dependent variable in columns (4) - (6) is an indicator for whether PAs can practice either remotely or quasi-remotely, i.e., the two less restrictive categories of physician supervision. Across all six specifications, neither nurse clout, nor non-physician clout, has a statistically significant effect, while physician and hospital clout have statistically significant effects consistent with the predicted effects. In the preferred specification for the effect of political spending on the probability PAs can practice remotely reported in column (3), a $10 \%$ increase in physician clout leads to a 0.54 percentage point decrease in the probability that PAs can practice remotely, while a $10 \%$ increase in hospital clout leads to a 0.68 percentage point increase in the probability that remote practice is allowed. In the preferred specification for the effect of spending on the probability of remote or quasi-remote practice reported in column (6), a $10 \%$ increase in physician clout decreases the probability of any type of remote practice by 0.68 percentage points, and a $10 \%$ increase in hospital clout increases this probability by 1.1 percentage points.

As with NP supervision laws, physician and hospital groups play a more salient role in determining PA supervision laws than do groups associated with PAs. In general, the magnitude of the effect of physician clout is smaller for PA supervision laws than for NP supervision laws in the preferred specifications. And hospital clout has a statistically significant effect across the range of laws granting greater PA autonomy instead of only at the highest level of autonomy as with NP supervision laws. Unlike NPs, PAs can never practice independently, so hospitals do not 
see a discontinuous jump in the benefits they enjoy from increased PA autonomy at the highest level of autonomy as they do with NPs. Hospitals may also be more focused on increasing PA autonomy because more PAs practice in hospitals than NPs (American Academy of Physician Assistants 2016; American Association of Nurse Practitioners 2016). Thus, hospitals likely benefit more from an increase in PA autonomy than in NP autonomy.

\section{Discussion}

In contrast to the majority of the existing literature, but consistent with conventional wisdom, the results presented here demonstrate that political spending by healthcare interest groups can affect whether states adopt different licensing laws. Thus, these results are consistent with and provide evidence supporting the investment theory of political spending, though they are not dispositive proof of this theory. Beyond the investment theory, the results suggest that, because physician and hospital groups have the most substantial impact on occupational licensing laws, the "battle" over NP and PA licensing laws may be better characterized as a rentseeking battle between hospitals and physicians as opposed to between NPs/PAs and physicians.

In general, a group's political clout over time matters most, as the effects of clout measured over four years are larger in magnitude and are more consistently statistically significant than the effects of clout measured over shorter time frames. To confirm that this is the case, I report two figures in the online appendix which plot the average political clout of all four groups in the five years preceding a change to Independence for NPs (Figure A1) or remote practice for PAs (Figure A2). In these figures, the legal change occurs in year 0, and only states that changed their laws are included. These figures suggest that there is not a spike in political clout across groups immediately leading up to a law change - though physician spending does increase two years prior to the passage of NP independence before decreasing again. 
In addition to illustrating how healthcare groups affect occupational licensing laws, the results presented here also provide greater context for the downstream effects of those laws. Prior work has characterized the decision of how to regulate NPs and PAs as exogenous or plausibly exogenous based on the idiosyncrasies of the political system (Stange 2014; see also Traczynski and Udalova 2014). While the political system may be idiosyncratic to some degree, the evidence above demonstrates that state regulation of NPs and PAs responds to changes in political spending by professional interest groups.

Finally, the results showing that licensing laws respond more strongly to spending by physician and hospital groups than to spending by nurse and non-physician groups are generally consistent with Wolton (2016). He suggests that campaign contributions by interest groups may serve as a signal of the resolve of those groups. Given that the resources of physician and hospital groups are much greater than those of nurse and non-physician groups, the large effects of physician and hospital groups and the small or statistically insignificant effects of nurse and non-physician groups are not surprising based on Wolton's (2016) approach.

\section{Extension}

The analysis presented above uses a logarithmic transformation of all clout variables, and the empirical specifications are based on Becker's (1983) model of interest group behavior and other models in a similar vein. To address the concern that the results above are artifacts of the use of logarithmic transformations and the concern that the results are unique to the underlying model of political spending, I employ a similar empirical strategy as De Figueiredo and Edwards (2007), who use Baron's (2001) model as the basis of their analysis of how contributions affect regulatory outcomes in the telecommunications industry. In Baron's common-agency model, a decisionmaker's choice of policy reflects contributions from two interest groups. The preferences 
of the decisionmaker and both interest groups are incorporated into the equilibrium outcome, and relative contributions matter more than absolute levels of contribution in equilibrium. Consistent with this model, De Figueiredo and Edwards (2007) find that regulations are friendlier to new entrant firms relative to incumbent firms as the proportion of total spending attributable to entrant firms increases.

For a measure of political spending attributable to nurse groups, I divide the sum of spending by nurse and hospital interest groups by the sum of spending by nurse, hospital, and physician interest groups to calculate the proportion of spending attributable to groups that favor broader NP licensing laws. For PAs, I do the same but replace nurse spending with nonphysician practitioner spending. I refer to the nurse and non-physician proportional spending variables as nurse proportion and non-physician proportion, respectively. As with the clout variables discussed above, I calculate proportional spending over the previous two, three, and four years. I use the same general specification described above but replace the clout variables with proportional spending variables. However, none of the proportional spending variables are transformed using a logarithmic (or any other) transformation. I do not include nurse (nonphysician) spending in the calculation of the non-physician proportion (nurse proportion) variable because it is not clear theoretically, strategically, or empirically, whether spending by nurse (non-physician) groups should be considered favorable or unfavorable to increased PA (NP) autonomy. Including nurse (non-physician) spending in the calculation of the non-physician proportion (nurse proportion) variable would, at best, introduce unnecessary measurement error and, at worst, result in systematic bias. ${ }^{8}$

Table 5 reports results from linear probability models with an indicator for NP independence as the dependent variable in the first three columns and an indicator for either NP 
independence or physician supervision of NP prescribing as the dependent variable in the last three columns. The results are consistent with earlier estimates. ${ }^{9}$ An increase in the proportion of spending attributable to NP-friendly groups results in an increase in the probability that a state grants greater autonomy to NPs. The estimated coefficients are statistically significant across all three temporal measures of nurse proportion. Table 6 reports results from linear probability models with an indicator for remote PA practice as the dependent variable in the first three columns and an indicator for whether PAs can practice remotely or quasi-remotely in the last three columns. The estimated effects are consistent with previous results. As with NPs, an increase in the spending attributable to PA-friendly groups results in an increase in the probability that PAs are granted greater autonomy.

\section{Robustness and Sensitivity}

\section{Rank Ordered Logit Models}

All robustness check results are reported in the online appendix. To determine whether increases in the political clout of different groups have consistent effects across the range of supervision laws, I estimate rank ordered logit models where the dependent variable is a ranking of physician supervision laws from least restrictive to most restrictive. Rank ordered logit models are generalizations of fixed effect logit models that can accommodate dependent variables with a ranked, but non-binary, structure. In these models generally, an actor ranks its preferences from first to last. Here, the actor is the state ranking physician supervision laws, and the highest ranked law is enacted. Within the context of physician supervision laws, rank ordered logit models can estimate the effect of a state moving to a less restrictive law given other alternatives.

I include the same general set of independent variables in the rank ordered logit models as in the general specification (except tort reforms, which must be excluded because of the way these models are estimated). Results for NP supervision laws and PA supervision laws are 
reported in Tables A7 and A8, respectively. Consistent with earlier results for NP supervision laws, an increase in physician clout (measured over four years) decreases the probability a state chooses a less restrictive supervision regime, while an increase in hospital clout (measured over four years) generates an increase in this probability. Similarly, an increase in physician (hospital) clout decreases (increases) the probability that PAs may practice with more autonomy.

\section{Other Specifications and Reverse Causation}

I first test whether the results are sensitive to the inclusion or exclusion of different control variables. The clout results are not sensitive to the choice of control variables, and Tables A9 and A10 report results from the main specifications with control variables excluded. Next, one possible explanation for the observed results is that states with higher overall political spending by certain groups are simply more likely to have broader licensing laws without any causal relationship between group spending and licensing laws. As a falsification test and to determine whether reverse causation is a problem, I estimate regressions - reported in Tables A11 and A12 - with future political spending as the dependent variable and indicators for NP and PA licensing laws as the independent variables. In general, I find no statistically significant effects of NP and PA licensing laws on future political spending, suggesting that, while political spending has an effect on state occupational licensing laws, changes in state laws do not affect spending going forward. In other words, I find no evidence of reverse causation.

\section{Endogeneity and Omitted Variables}

Throughout the analysis, I treat the contribution mixes between groups as exogenous. While all specifications control for state and time fixed effects, time-varying shocks to relative group profitability could potentially alter the contribution mix across groups. The nature of the laws and groups considered here mitigate this concern to a substantial degree. Any regulatory or 
economic shock to one group will very likely affect the other groups in a similar manner, as all groups operate within the healthcare industry.

Another potential problem is the possibility that changes in campaign finance laws are correlated with changes in healthcare licensing laws. However, this is unlikely because (1) campaign finance and healthcare are not generally connected in any systematic manner and (2) between 1999 and 2009, the number of states with limits on contributions to candidates did not change (Milyo 2012). With the 2010 Citizens United Supreme Court case, which affected campaign finance laws nationwide, there were no changes in state law concerning contributions to candidates that would not be controlled for by state and time fixed effects. However, four states enacted bans on corporate independent expenditures between 1999 and 2009 (Werner and Coleman 2015). Including these bans in the models above does not meaningfully change the results, and results with indicators for bans included are reported in Tables A13 and A14.

Next, I test for omitted variable bias generally. I employ the method developed by Oster (2016), which provides a formal approach to test for omitted variable bias based on coefficient stability. Oster's approach draws on prior work by Altonji et al. (2008), Tamer (2010), and Manski (2003), and a similar approach was used by De Figueiredo and Edwards (2007) to test their empirical models for omitted variable bias. This approach includes a proportional selection assumption so that the amount of selection of the potentially endogenous variable on the other observed explanatory variables is proportional to the amount of selection on the unobserved variables and the extent of any endogeneity bias. Following Oster (2016) and Altjoni et al. (2008), I assume equal selection - i.e., the amount of selection on the observed and unobserved variables is the same - and a conservative estimate for the maximum R-squared in my models. Given these assumptions, I construct an identified set along the lines of Tamer (2010) and 
Manksi (2003) for each of the political spending variables in the main specifications above. Oster (2016) suggests a rule of thumb that, if the identified set of a given effect excludes zero, there is evidence of causality. None of the identified sets-reported in Tables A15 and A16associated with any statistically significant effect above includes zero.

\section{Mechanism}

While political clout affects legal outcomes, an increase in political clout can occur for several reasons. Increased clout may, for example, reflect an increase in the number of group members, an increase in spending per member, or an increase in a group's spending efficiency. To test whether the clout of each professional group is related to the size of that group within each state (which determined the amount of spending in Becker's (1983) original model), I regress the clout of each group on the proportion of a state's population employed as a member

of that group. ${ }^{10}$ In ordinary least squares specifications with state and time fixed effects, I find no statistically significant evidence that an increase in the proportion of a state's population employed as a member of a given group increases that group's clout. These results, which are reported in Table A17, demonstrate that the effects of changes in political clout are not driven by changes in the number of members of a given professional group.

\section{Conclusion}

Previous work has highlighted some of the effects of licensing laws on NPs and PAs, but no study has considered why these laws exist in the form they do. The findings presented here suggest that political spending by professional interest groups plays a role in states' choices of occupational licensing laws. An increase in spending by physician (hospital) groups decreases (increases) the probability that states impose less restrictive physician supervision requirements on NPs and PAs. In general, the evidence presented here is consistent with the investment theory 
of political spending, as groups invest political dollars and receive benefits in the form of their preferred licensing laws in return.

The results presented here may also be useful in ascertaining the costs imposed on society by the political spending of healthcare interest groups. For example, Kleiner et al. (2016) find that allowing NPs to practice independently can reduce the cost of a well-child examination by about $\$ 16$ relative to requiring complete supervision of NPs. In Georgia, which had a population of approximately 10 million people in 2012, physician interest groups spent about $\$ 600,000$. About 2.5 million Georgia residents were under 18 and thus could have received a well-child examination. Georgia requires complete supervision of NPs, but by moving to independent practice, Georgia could save its healthcare consumers approximately $\$ 8$ million if only $20 \%$ of Georgia children realize the savings estimated by Kleiner et al. (2016).

As noted above, 19 of 51 jurisdictions allowed NPs to practice independently in 2013, which corresponds to a probability of approximately 0.4 of a given state allowing NP independence. Assuming this was the probability of Georgia allowing NPs to practice independently in 2013, the expected savings on well-child examinations in Georgia was \$3.2 million. If physicians had increased their per capita spending by $100 \%$, the results presented here imply that the probability of Georgia allowing NP independence would have decreased from 0.4 to 0.3 , which implies the expected savings in Georgia would have decreased to $\$ 2.4$ million (a loss of $\$ 800,000)$. From the physician perspective, spending the additional money is rational (\$600,000 across all physicians in Georgia amounts to less than $\$ 30$ per physician). However, from a societal perspective, this behavior by physicians represents inefficient rent-seeking. While this "back-of-the-envelope" example is meant only as an illustration, it shows that political spending can affect the healthcare system and impose significant costs on consumers. 


\section{References}

Adams, A. Frank, III, Robert Ekelund, and John Jackson. 2003. Occupational Licensing of a Credence Good: The Regulation of Midwifery. Southern Economic Journal 69:659-675.

Altonji, Joseph G., Todd Elder, and Christopher R. Taber. 2008. Using Selection on Observed Variables to Assess Bias from Unobservables When Evaluating Swan-Ganz Catheterization. American Economic Review 98:345-50.

American Academy of Physician Assistants. 2014. 2013 AAPA Annual Survey Report, available at https://www.aapa.org/WorkArea/DownloadAsset.aspx?id=2902.

American Association of Nurse Practitioners. 2016. NP Fact Sheet, available at https://www.aanp.org/all-about-nps/np-fact-sheet.

Ansolabehere, Stephen, John M. de Figueiredo, and James M. Snyder Jr. 2003. Why is there So Little Money in U.S. Politics? Journal of Economic Perspectives 17:105-130.

Ansolabehere, Stephen, James Snyder, and Micky Tripathi. 2002. Are PAC Contributions and Lobbying Linked? New Evidence from the 1995 Lobby Disclosure Act. Business and Politics 4:131-155.

Avraham, Ronen. 2014. "Database of State Tort Law Reforms (DSTLR 5th)," University of Texas Law, Law and Econ Research Paper No. e555. Available at SSRN: https://papers.ssrn.com/sol3/papers.cfm?abstract_id=902711.

Avraham, Ronen, and Max Schanzenbach. 2010. The Impact of Tort Reform on Private Health Insurance Coverage. American Law and Economics Review 10:319-355.

Avraham, Ronen, and Max Schanzenbach. 2015. The impact of tort reform on intensity of treatment: Evidence from heart patients. Journal of Health Economics 39:273-288. 
Auerbach, David. 2012. Will the NP Workforce Grow in the Future?: New Forecasts and Implications for Healthcare Delivery. Medical Care 50:606-610.

Baron, David P. 2001. Theories of Strategic Nonmarket Participation: Majority-Rule and Executive Institutions. Journal of Economic and Management Strategy 10:47-89.

Becker, Gary S. 1983. A Theory of Competition among Pressure Groups for Political Influence. Quarterly Journal of Economics 98:371-400.

Brown, Sharon, and Deanna Grimes. 1995. A Meta-Analysis of Nurse Practitioners and Nurse Midwives in Primary Care. Nursing Research 44:332-339.

De Figueiredo, Rui J., and Geoff Edwards. 2007. Does Private Money Buy Public Policy? Campaign Contributions and Regulatory Outcomes in Telecommunications. Journal of Economic and Management Strategy 16:547-576.

Dueker, Michael J., Ada K. Jacox, David E. Kalist, and Stephen J. Spurr. 2005. The Practice Boundaries of Advanced Practice Nurses: An Economic and Legal Analysis. Journal of Regulatory Economics 27:309-329.

Feldstein, Paul. 2011. Health Care Economics. Albany, New York: Delmar Publishers.

Gilman, Daniel J. and Tara Isa Koslov. 2014. Policy Perspectives: Competition and the Regulation of Advanced Practice Nurses, Federal Trade Commission Report.

Grossman, Gene M. and Elhanan Helpman. 1994. Protection for Sale. American Economic Review 84:833-850.

Hall, Richard L., and Frank W. Wayman. 1990. Buying Time: Moneyed Interests and the Mobilization of Bias in Congressional Committees. American Political Science Review 84:797-820. 
Institute of Medicine. 2011. The Future of Nursing: Leading Change, Advancing Health. Washington, DC: The National Academies Press.

Kleiner, Morris M., Allison Marier, Kyoung Won Park, and Coady Wing. 2016. Relaxing Occupational Licensing Requirements: Analyzing Wages and Prices for a Medical Service. Journal of Law and Economics 59:261-291.

Kleiner, Morris M., and Robert Kudrle. 2000. Does Regulation Affect Economic Outcomes? The Case of Dentistry. Journal of Law and Economics 43:547-576.

Laurant, Miranda, Mirjam Harmsen, Hub Wollersheim, Richard Grol, Marjan Faber, and Bonnie Sibbald. 2009. The Impact of Non-physician clinicians: do they improve the quality and cost effectiveness of health care services. Medical Care Research and Review 66:36s$55 \mathrm{~s}$.

Letz, Elizabeth R., Mary O. Mundinger, Robert L. Kane, Sarah C. Hopkins, and Susan X. Lin. 2004. Primary Care Outcomes in Patients Treated by Nurse Practitioners or Physicians: Two-Year Follow Up. Medical Care Research 61:332-351.

Manski, Charles F. Partial Identification of Probability Distributions: Springer Series in Statistics, Springer, 2003.

Milyo, Jeff. 2012. Do State Campaign Finance Reforms Increase Trust and Confidence in State Government?, University of Missouri Working Paper No. 13-01.

Mundinger, Mary O., Robert L Kane, Elizabeth R. Lenz, Annette M. Totten, Wei-Yann Tsai, Paul D. Cleary, William T. Friedwall, Albert L Siu, and Michael L Shelanski. 2000. Primary Care Outcomes in Patients Treated by Nurse Practitioners or Physicians. Journal of the American Medical Association 283:59-68. 
National Governors Association. 2012. The Role of Nurse Practitioners in Meeting Increasing Demands for Primary Care, National Governors Association Paper.

National Governors Association. 2014. The Role of Physician Assistants in Health Care Delivery, National Governors Association Paper.

National Institute on Money in State Politics. 2014. Database of State Political Campaign Contributions. Available at http://www.followthemoney.org/.

Newhouse, Robin P., Julie Stanik-Hutt, Kathleen M. White, Meg Johantgen, Eric B. Bass, George Zangaro, Renee F. Wilson, Lily Fountain, Donald M. Steinwachs, Lou Heindel, and Jonathan P. Weiner. 2011. Advanced Practice Nurse Outcomes1990-2008: A Systematic Review. Nursing Economics 29:230-250.

Office of Economic Policy of the Department of the Treasury, Council of Economic Advisers, Department of Labor. 2015. Occupational Licensing: A Framework for Policymakers.

Oster, Emily. 2016. "Unobservable Selection and Coefficient Stability: Theory and Validation." Journal of Business Economics and Statistics, forthcoming.

Peltzman, Sam. 1976. Toward a More General Theory of Regulation. Journal of Law and Economics 19:211-240.

Perry, John J. 2009. The Rise and Impact of Nurse Practitioners and Physician Assistants on Their Own and Cross-Occupation Incomes. Contemporary Economic Policy 27:491-511.

Persico, Nicola. 2015. The Political Economy of Occupational Licensing Associations. Journal of Law, Economics, \& Organization 31:213-241.

Shephard, Lawrence. 1978. Licensing Restrictions and the Cost of Dental Care. Journal of Law and Economics 21:187-201. 
Snyder, James. 1992. Long-Term Investing in Politicians; Or, Give Early, Give Often. Journal of Law and Economics 35:15-43.

Stange, Kevin. 2014. How Does Provider Supply and Regulation Influence Health Care Markets? Evidence from Nurse Practitioners and Physician Assistants. Journal of Health Economics 33:1-27.

Stigler, George. 1971. The Theory of Economic Regulation. Bell Journal of Economics and Management Science 2:3-21.

Tamer, Elie, Partial Identification in Econometrics. 2010. Annual Review of Economics 9:167195.

Thornton, Robert, and Edward Timmons. 2013. Licensing One of the World's Oldest Professions: Massage. Journal of Law and Economics 56:371-388.

Timmons, Edward, and Robert Thornton. 2008. The Effects of Licensing on the Earnings of Radiologic Technologists. Journal of Labor Research 29:333-346.

Traczynski, Jeffrey, and Victoria Udalova. 2014. Nurse Practitioner Independence, Health Care Utilization, and Health Outcomes. Working Paper, available at http://www2.hawaii.edu/ jtraczyn/paperdraft_050414_ASHE.pdf.

Werner, Timothy, and John J. Coleman. 2015. Citizens United, Independent Expenditures, and Agency Costs: Reexamining the Political Economic of State Antitakeover Statutes. Journal of Law, Economics, \& Organization 31:127-159.

Wolton, Stephane. 2016. Lobbying, Inside and Out: How Special Interest Groups Influence Policy Choices. Working paper, available at https://papers.ssrn.com/sol3/papers.cfm?abstract_id=2190685. 
${ }^{1}$ Prior to 1998, Medicare only reimbursed NPs and PAs for providing services "incident to" physician services, 
meaning that, even if they could practice independently, Medicare (and most private insurance companies and state Medicaid programs) would not reimburse NPs and PAs for their services.

${ }^{2}$ The Institute also provides data on individual contributions. However, because I cannot observe the purpose of individual contributions and because individual physicians, nurses, etc. may contribute for reasons unrelated to their profession (e.g., they may care deeply about tax reform), I do not consider individual contributions in my analysis. This is not a problem for interest group contributions, as these contributions must be related to the group's purpose. ${ }^{3}$ Depending on the assumptions about the nature of a group one is willing to make based on ambiguous group names, physical therapists generally represent around $50 \%$ of the groups in this category, while PA groups generally represent between $35 \%$ and $45 \%$. Because these percentages can vary wildly based on the inclusion/exclusion of ambiguously named groups, I do not separate PA groups from other groups. Doing so presents serious risks of arbitrary categorization of a large number of groups.

${ }^{4}$ For both the nurse and non-physician categories, I compare the proportion of groups (and spending) attributable to groups clearly identified as NP-specific and PA-specific, respectively, across states and time. For the nurse category, I find no statistically significant evidence that the share of groups that are clearly identified as NP-specific varies in a systematic way across states or time. Similarly, for the non-physician category, I find no statistically significant evidence that groups clearly identified as PA-specific systematically make up a different proportion of the overall non-physician category across states or time. This lack of evidence suggests that, while using nurse and non-physician categories results in some measurement error, using these broader group categories does not bias the results discussed below.

${ }^{5}$ States with democratic governors may be more likely to grant NPs and PAs more autonomy because doing so is often viewed as increasing access to healthcare—a policy goal that democrats have pursued in other arenas (e.g., the Affordable Care Act).

${ }^{6}$ The effect of nurse (non-physician) spending on PA (NP) supervision laws is not clear, as each profession may have different preferences for the other depending on various circumstances. Results with nurse spending (nonphysician spending) excluded from the PA law specifications (NP law specifications) are reported in Tables A1 and A2 in the online appendix. The results are generally consistent with the main results reported below. 
${ }^{7}$ While it is not possible to completely rule out the possibility that the nurse clout results may be affected by measurement error as a result of including the spending of non-NP-specific groups in the calculation of nurse clout, the nurse clout coefficients are precisely estimated across all specifications.

${ }^{8}$ In the interest of completeness, I report results with nurse spending (non-physician spending) included in the calculation of the non-physician proportion (nurse proportion) variables in Tables A5 and A6.

${ }^{9}$ The regressions in Table 5 include fewer observations than previous regressions because some states had no political spending by a professional group in certain years, making the nurse proportion variable undefined. Replacing undefined nurse proportion variables with 1 (i.e., all political spending is attributable to NP-friendly groups), 0 (i.e., all political spending is attributable to physician-friendly groups), or 0.5 does not change the qualitative nature of the results.

${ }^{10}$ Data on the proportion of a state's population employed as a member of each group come from the Bureau of Labor Statistics' Occupational Employment Statistics Program. I include nurses of all types in the nurse category and physicians of all types in the physician category. In the non-physician category, I include all professions which have a professional organization appearing at least once in the campaign contribution data. Including only NPs and only PAs does not change the results. 
Tables

Table 1: Licensing Laws from 1999 through 2013

Panel A: Physician Supervision Laws for NPs

\begin{tabular}{|c|c|c|}
\hline Always Independence & $\begin{array}{c}\text { Always Prescription } \\
\text { Supervision } \\
\end{array}$ & $\begin{array}{c}\begin{array}{c}\text { Always Complete } \\
\text { Supervision }\end{array} \\
\end{array}$ \\
\hline $\begin{array}{l}\text { AK, DC, IA, ME, MT, NH, } \\
\text { NM, OR, UT, WY }\end{array}$ & $\begin{array}{l}\text { AR, IN, MI, NJ, OK, RI, } \\
\text { WV }\end{array}$ & $\begin{array}{l}\text { AL, CA, CT, DE, FL, GA, } \\
\text { IL, KS, LA, MN, MS, MO, } \\
\text { NE, NV, NY, NC, OH, PA, } \\
\text { SC, SD, TN, VA, WI }\end{array}$ \\
\hline $\begin{array}{l}\text { Change from Complete to } \\
\text { Prescription Supervision }\end{array}$ & $\begin{array}{c}\text { Change from Complete } \\
\text { Supervision to } \\
\text { Independence }\end{array}$ & $\begin{array}{c}\text { Change from Prescription } \\
\text { Supervision to } \\
\text { Independence }\end{array}$ \\
\hline $\begin{array}{l}\text { KY (2001), MA (2012), } \\
\text { MD (2011) }\end{array}$ & ID (2005), VT (2011) & $\begin{array}{l}\text { AZ (2000), CO (2010), HI } \\
(2010), \text { MD (2012), ND } \\
(2011), \text { WA }(2001)\end{array}$ \\
\hline TX $(2002)^{\mathrm{a}}$ & & \\
\hline
\end{tabular}

Panel B: Physician Supervision Laws for PAs

\begin{tabular}{|c|c|c|}
\hline Always Remote Practice & $\begin{array}{c}\text { Always Quasi-Remote } \\
\text { Practice }\end{array}$ & $\begin{array}{l}\text { Always Onsite } \\
\text { Supervision }\end{array}$ \\
\hline $\begin{array}{l}\text { AK, CA, HI, KS, KY, LA, } \\
\text { ME, MD, MA, MI, MN, } \\
\text { MT, NE, NH, NY, NC, TN, } \\
\text { VT, VA, WI, WY }\end{array}$ & $\mathrm{AL}, \mathrm{AZ}, \mathrm{IA}, \mathrm{NJ}, \mathrm{OK}, \mathrm{WA}$ & $\begin{array}{l}\text { AR, DE, FL, GA, IL, IN, } \\
\text { MS, OH, PA, SC, WV }\end{array}$ \\
\hline $\begin{array}{c}\text { Change from Onsite to } \\
\text { Quasi-remote }\end{array}$ & $\begin{array}{c}\text { Change from Onsite to } \\
\text { Remote }\end{array}$ & $\begin{array}{c}\text { Change from Quasi- } \\
\text { remote to Remote }\end{array}$ \\
\hline $\begin{array}{l}\text { MO (2010), OR (2002), TX } \\
(2003)\end{array}$ & $\begin{array}{l}\text { CO (2006), DC (2008), ID } \\
(1999), \text { RI (2002), UT } \\
(2002)\end{array}$ & $\begin{array}{l}\text { CT (2008), NV (1999), NM } \\
(2006), \text { ND (2003), OR } \\
(2010), \text { SD (2008) }\end{array}$ \\
\hline
\end{tabular}

Note: All reported years reflect the first year a state is coded as having the new law. If a state enacted a law in the second half of a given calendar year, it is not coded as having that new law in place until the following calendar year. ${ }^{\text {a }}$ Texas amended its law to move from prescription supervision to complete supervision in 2002. 


\section{Table 2: Summary Statistics}

\begin{tabular}{lrc}
\hline Variables & Mean & Std. dev. \\
\hline & & \\
Physician clout & 26.31 & 48.24 \\
$\quad$ Physicians Generally & 17.37 & 37.70 \\
$\quad$ Specialist Physicians & 8.94 & 16.48 \\
Nurse clout & 1.29 & 2.47 \\
Non-physician clout & 1.38 & 2.09 \\
Hospital clout & 28.98 & 49.53 \\
& & \\
\hline
\end{tabular}

Note: $\mathrm{N}=765$. All clout variables are defined as the amount of political spending by the relevant group per 1,000 state residents. All spending has been adjusted to 2013 dollars. 
Table 3: Linear Probability Model Results for NP Supervision Laws

\begin{tabular}{|c|c|c|c|c|c|c|}
\hline Variables & $\begin{array}{c}\text { (1) } \\
\text { I(NP Indep) }\end{array}$ & $\begin{array}{c}(2) \\
\text { I(NP Indep) } \\
\end{array}$ & $\begin{array}{c}3) \\
\text { I(NP Indep) }\end{array}$ & $\begin{array}{c}(4) \\
\text { I(Less Super) }\end{array}$ & $\begin{array}{c}5) \\
\text { I(Less Super) }\end{array}$ & $\begin{array}{c}\text { (6) } \\
\text { I(Less Super) }\end{array}$ \\
\hline Log(Nurse clout) (2-year) & $\begin{array}{c}0.006 \\
(0.004)\end{array}$ & & & $\begin{array}{c}0.008 * \\
(0.004)\end{array}$ & & \\
\hline Log(Non-physician clout) (2-year) & $\begin{array}{c}0.002 \\
(0.004)\end{array}$ & & & $\begin{array}{c}0.003 \\
(0.009)\end{array}$ & & \\
\hline Log(Physician clout) (2-year) & $\begin{array}{l}-0.026^{* *} \\
(0.011)\end{array}$ & & & $\begin{array}{l}-0.030 \\
(0.018)\end{array}$ & & \\
\hline Log(Hospital clout) (2-year) & $\begin{array}{c}0.014 \\
(0.013)\end{array}$ & & & $\begin{array}{c}0.007 \\
(0.020)\end{array}$ & & \\
\hline Log(Nurse clout) (3-year) & & $\begin{array}{c}0.010^{*} \\
(0.005)\end{array}$ & & & $\begin{array}{c}0.017 * \\
(0.009)\end{array}$ & \\
\hline Log(Non-physician clout) (3-year) & & $\begin{array}{c}0.003 \\
(0.005)\end{array}$ & & & $\begin{array}{c}0.005 \\
(0.009)\end{array}$ & \\
\hline Log(Physician clout) (3-year) & & $\begin{array}{l}-0.048 * * * \\
(0.012)\end{array}$ & & & $\begin{array}{l}-0.049 * * \\
(0.021)\end{array}$ & \\
\hline Log(Hospital clout) (3-year) & & $\begin{array}{l}0.029 * * \\
(0.014)\end{array}$ & & & $\begin{array}{c}0.012 \\
(0.027)\end{array}$ & \\
\hline Log(Nurse clout) (4-year) & & & $\begin{array}{c}0.012 * \\
(0.007)\end{array}$ & & & $\begin{array}{r}0.022 * \\
(0.013)\end{array}$ \\
\hline Log(Non-physician clout) (4-year) & & & $\begin{array}{c}0.000 \\
(0.005)\end{array}$ & & & $\begin{array}{c}0.004 \\
(0.010)\end{array}$ \\
\hline Log(Physician clout) (4-year) & & & $\begin{array}{l}-0.096 * * * \\
(0.035)\end{array}$ & & & $\begin{array}{l}-0.092^{* * *} \\
(0.041)\end{array}$ \\
\hline Log(Hospital clout) (4-year) & & & $\begin{array}{l}0.078 * * \\
(0.035)\end{array}$ & & & $\begin{array}{c}0.052 \\
(0.045)\end{array}$ \\
\hline $\begin{array}{l}\text { Observations } \\
\text { R-squared }\end{array}$ & $\begin{array}{c}765 \\
0.895\end{array}$ & $\begin{array}{c}765 \\
0.897\end{array}$ & $\begin{array}{c}765 \\
0.900\end{array}$ & $\begin{array}{c}765 \\
0.921\end{array}$ & $\begin{array}{c}765 \\
0.923\end{array}$ & $\begin{array}{c}765 \\
0.924\end{array}$ \\
\hline
\end{tabular}


Note: The dependent variable in the first three columns is an indicator for whether a state allowed independent NP practice in a given year. The dependent variable in the final three columns is an indicator that takes the value one if a state allowed NPs to practice independently or required physician supervision only when NPs prescribe medications. All specifications include state and year fixed effects. Other covariates include the percentage of the population covered by Medicaid, by Medicare, and by private insurance; the percentage of the population that identifies as black; the population density of the state; the median income of the state; and indicators for a democratic governor, democratic legislature, republican legislature, noneconomic damages cap, collateral source rule reform, and joint and several liability reform. Standard errors clustered at the state level are reported in parentheses.

*** significant at $1 \%$ level; ** significant at $5 \%$ level; * significant at $10 \%$ level. 
Table 4: Linear Probability Model Results for PA Supervision Laws

\begin{tabular}{|c|c|c|c|c|c|c|}
\hline Variables & $\begin{array}{c}(1) \\
\text { I(Remote) }\end{array}$ & $\begin{array}{c}(2) \\
\text { I(Remote) }\end{array}$ & $\begin{array}{c}(3) \\
\text { I(Remote) }\end{array}$ & $\begin{array}{c}(4) \\
\text { I(Less Super) }\end{array}$ & $\begin{array}{c}5) \\
\text { I(Less Super) }\end{array}$ & $\begin{array}{c}6) \\
\text { I(Less Super) }\end{array}$ \\
\hline Log(Non-physician clout) (2-year) & $\begin{array}{l}-0.003 \\
(0.006)\end{array}$ & & & $\begin{array}{l}-0.006 \\
(0.008)\end{array}$ & & \\
\hline Log(Nurse clout) (2-year) & $\begin{array}{l}-0.010 \\
(0.009)\end{array}$ & & & $\begin{array}{l}-0.011 \\
(0.016)\end{array}$ & & \\
\hline Log(Physician clout) (2-year) & $\begin{array}{l}-0.053 * * * \\
(0.011)\end{array}$ & & & $\begin{array}{l}-0.058 * * * \\
(0.014)\end{array}$ & & \\
\hline Log(Hospital clout) (2-year) & $\begin{array}{l}0.059 * * * \\
(0.019)\end{array}$ & & & $\begin{array}{l}0.075 * * * \\
(0.026)\end{array}$ & & \\
\hline Log(Non-physician clout) (3-year) & & $\begin{array}{l}-0.006 \\
(0.007)\end{array}$ & & & $\begin{array}{l}-0.014 \\
(0.008)\end{array}$ & \\
\hline Log(Nurse clout) (3-year) & & $\begin{array}{l}-0.010 \\
(0.011)\end{array}$ & & & $\begin{array}{l}-0.012 \\
(0.019)\end{array}$ & \\
\hline Log(Physician clout) (3-year) & & $\begin{array}{l}-0.053 * * * \\
(0.014)\end{array}$ & & & $\begin{array}{l}-0.064 * * * \\
(0.021)\end{array}$ & \\
\hline Log(Hospital clout) (3-year) & & $\begin{array}{l}0.065 * * \\
(0.028)\end{array}$ & & & $\begin{array}{l}0.097 * * \\
(0.046)\end{array}$ & \\
\hline Log(Non-physician clout) (4-year) & & & $\begin{array}{l}-0.008 \\
(0.009)\end{array}$ & & & $\begin{array}{l}-0.021 \\
(0.013)\end{array}$ \\
\hline Log(Nurse clout) (4-year) & & & $\begin{array}{l}-0.009 \\
(0.012)\end{array}$ & & & $\begin{array}{l}-0.009 \\
(0.021)\end{array}$ \\
\hline $\log$ (Physician clout) (4-year) & & & $\begin{array}{l}-0.054 * * * \\
(0.018)\end{array}$ & & & $\begin{array}{l}-0.068 * * \\
(0.028)\end{array}$ \\
\hline Log(Hospital clout) (4-year) & & & $\begin{array}{l}0.068 * * \\
(0.033)\end{array}$ & & & $\begin{array}{c}0.110^{*} \\
(0.056)\end{array}$ \\
\hline $\begin{array}{l}\text { Observations } \\
\text { R-squared }\end{array}$ & $\begin{array}{c}765 \\
0.888\end{array}$ & $\begin{array}{c}765 \\
0.887\end{array}$ & $\begin{array}{c}765 \\
0.887\end{array}$ & $\begin{array}{c}765 \\
0.904\end{array}$ & $\begin{array}{c}765 \\
0.904\end{array}$ & $\begin{array}{c}765 \\
0.905\end{array}$ \\
\hline
\end{tabular}


Note: The dependent variable in the first three columns is an indicator for whether a state allowed PAs to practice remotely. The dependent variable in the last three columns is an indicator for whether PAs were allowed to practice either remotely or quasi-remotely. All specifications include state and year fixed effects. Other covariates include the percentage of the population covered by Medicaid, by Medicare, and by private insurance; the percentage of the population that identifies as black; the population density of the state; the median income of the state; and indicators for a democratic governor, democratic legislature, republican legislature, noneconomic damages cap, collateral source rule reform, and joint and several liability reform. Standard errors clustered at the state level are reported in parentheses. *** significant at $1 \%$ level; ** significant at $5 \%$ level; * significant at $10 \%$ level. 
Table 5: Linear Probability Model Results for NP Supervision Laws (Common-Agency Model)

\begin{tabular}{|c|c|c|c|c|c|c|}
\hline Variables & $\begin{array}{c}(1) \\
\text { I(NP Indep) }\end{array}$ & $\begin{array}{c}(2) \\
\text { I(NP Indep) } \\
\end{array}$ & $\begin{array}{c}(3) \\
\text { I(NP Indep) }\end{array}$ & $\begin{array}{c}(4) \\
\text { I(Less Super) } \\
\end{array}$ & $\begin{array}{c}(5) \\
\text { I(Less Super) } \\
\end{array}$ & $\begin{array}{c}(6) \\
\text { I(Less Super) }\end{array}$ \\
\hline Nurse Proportion (2-year) & $\begin{array}{c}0.319 * \\
(0.186)\end{array}$ & & & $\begin{array}{c}0.549 * \\
(0.320)\end{array}$ & & \\
\hline Nurse Proportion (3-year) & & $\begin{array}{c}0.464^{*} \\
(0.239)\end{array}$ & & & $\begin{array}{c}0.818^{*} \\
(0.410)\end{array}$ & \\
\hline Nurse Proportion (4-year) & & & $\begin{array}{c}0.598 * \\
(0.332)\end{array}$ & & & $\begin{array}{c}0.974^{*} \\
(0.522)\end{array}$ \\
\hline Observations & 757 & 760 & 760 & 757 & 760 & 760 \\
\hline R-squared & 0.894 & 0.895 & 0.895 & 0.920 & 0.921 & 0.921 \\
\hline
\end{tabular}

Note: The dependent variable in the first three columns is an indicator for whether a state allowed independent NP practice in a given year. The dependent variable in the final three columns is an indicator that takes the value one if a state allowed NPs to practice independently or required physician supervision only when NPs prescribe medications. All specifications include state and year fixed effects. Other covariates include the percentage of the population covered by Medicaid, by Medicare, and by private insurance; the percentage of the population that identifies as black; the population density of the state; the median income of the state; and indicators for a democratic governor, democratic legislature, republican legislature, noneconomic damages cap, collateral source rule reform, and joint and several liability reform. Standard errors clustered at the state level are reported in parentheses.

*** significant at $1 \%$ level; ** significant at $5 \%$ level; * significant at $10 \%$ level. 
Table 6: Linear Probability Model Results for PA Supervision Laws (Common-Agency Model)

\begin{tabular}{|c|c|c|c|c|c|c|}
\hline Variables & $\begin{array}{c}(1) \\
\text { I(Remote) }\end{array}$ & $\begin{array}{c}(2) \\
\text { I(Remote) }\end{array}$ & $\begin{array}{c}\text { (3) } \\
\text { I(Remote) }\end{array}$ & $\begin{array}{c}(4) \\
\text { I(Less Super) }\end{array}$ & $\begin{array}{c}(5) \\
\text { I(Less Super) }\end{array}$ & $\begin{array}{c}(6) \\
\text { I(Less Super) }\end{array}$ \\
\hline Non-physician Proportion (2-year) & $\begin{array}{l}0.341 * * \\
(0.158)\end{array}$ & & & $\begin{array}{c}0.368 * \\
(0.198)\end{array}$ & & \\
\hline Non-physician Proportion (3-year) & & $\begin{array}{l}0.480 * * \\
(0.210)\end{array}$ & & & $\begin{array}{c}0.553 \\
(0.343)\end{array}$ & \\
\hline Non-physician Proportion (4-year) & & & $\begin{array}{l}0.482 * * \\
(0.210)\end{array}$ & & & $\begin{array}{c}0.545 \\
(0.367)\end{array}$ \\
\hline Observations & 765 & 765 & 765 & 765 & 765 & 765 \\
\hline R-squared & 0.887 & 0.887 & 0.887 & 0.904 & 0.904 & 0.904 \\
\hline
\end{tabular}

Note: The dependent variable in the first three columns is an indicator for whether a state allowed PAs to practice remotely. The dependent variable in the last three columns is an indicator for whether PAs were allowed to practice either remotely or quasi-remotely. All specifications include state and year fixed effects. Other covariates include the percentage of the population covered by Medicaid, by Medicare, and by private insurance; the percentage of the population that identifies as black; the population density of the state; the median income of the state; and indicators for a democratic governor, democratic legislature, republican legislature, noneconomic damages cap, collateral source rule reform, and joint and several liability reform. Standard errors clustered at the state level are reported in parentheses. $* * *$ significant at $1 \%$ level; ** significant at $5 \%$ level; * significant at $10 \%$ level. 
Figure Captions

Figure 1: Political Clout over Time 


\section{Figures}

\section{Figure 1}

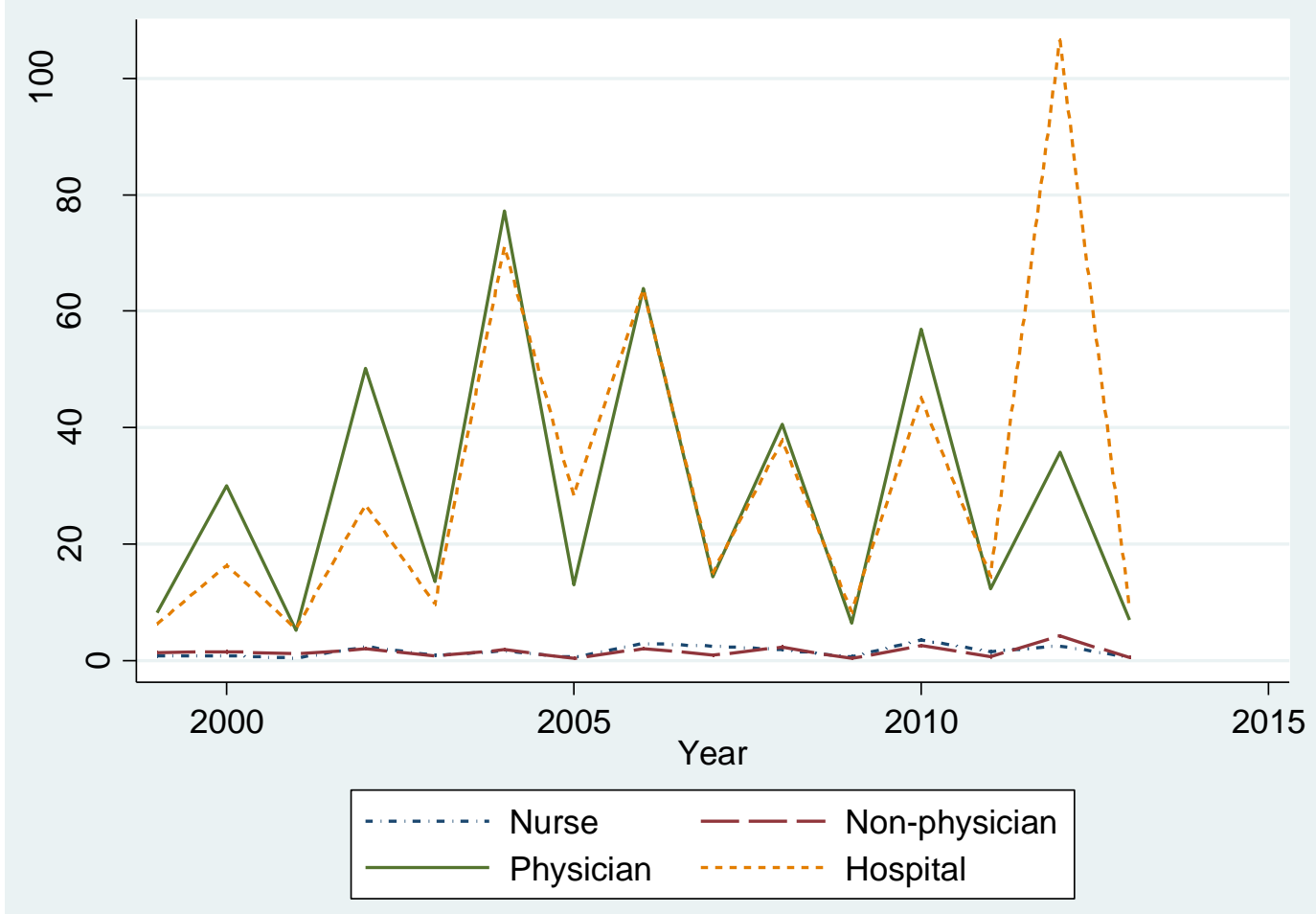




\begin{abstract}
Appendix*
*For Online Publication Only. This appendix is included here for the benefit of the editor(s) and referee(s) and is not designed to be included in the publication version.
\end{abstract}

Figure A1: Political Clout Prior to Passage of Independence for NPs

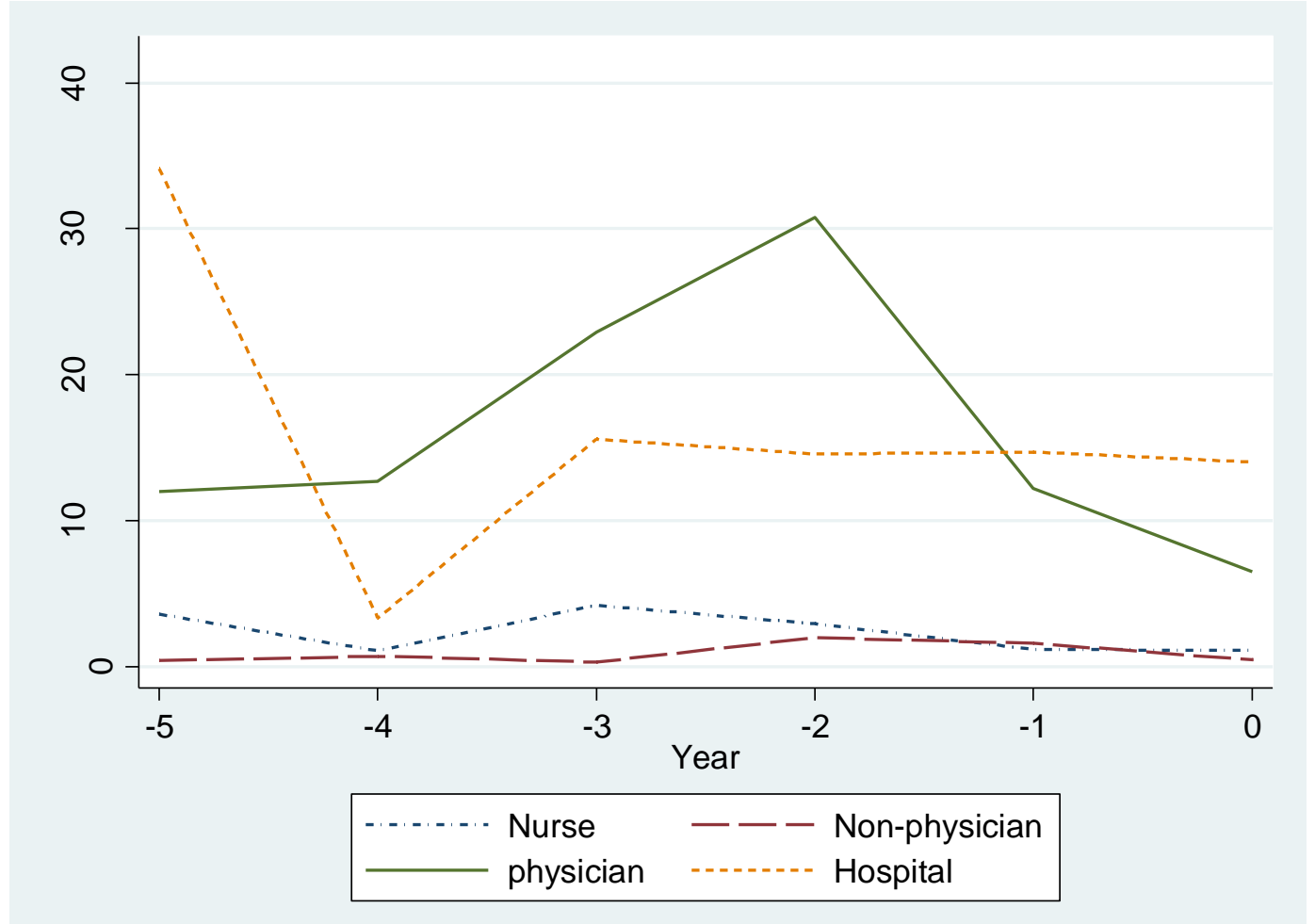

Note: A legal change occurs at zero, and this figure reports the average clout of different groups in the five years preceding that change. Only states that actually experienced a change are included in this figure. 
Figure A2: Political Clout Prior to Passage of Remote Practice for PAs

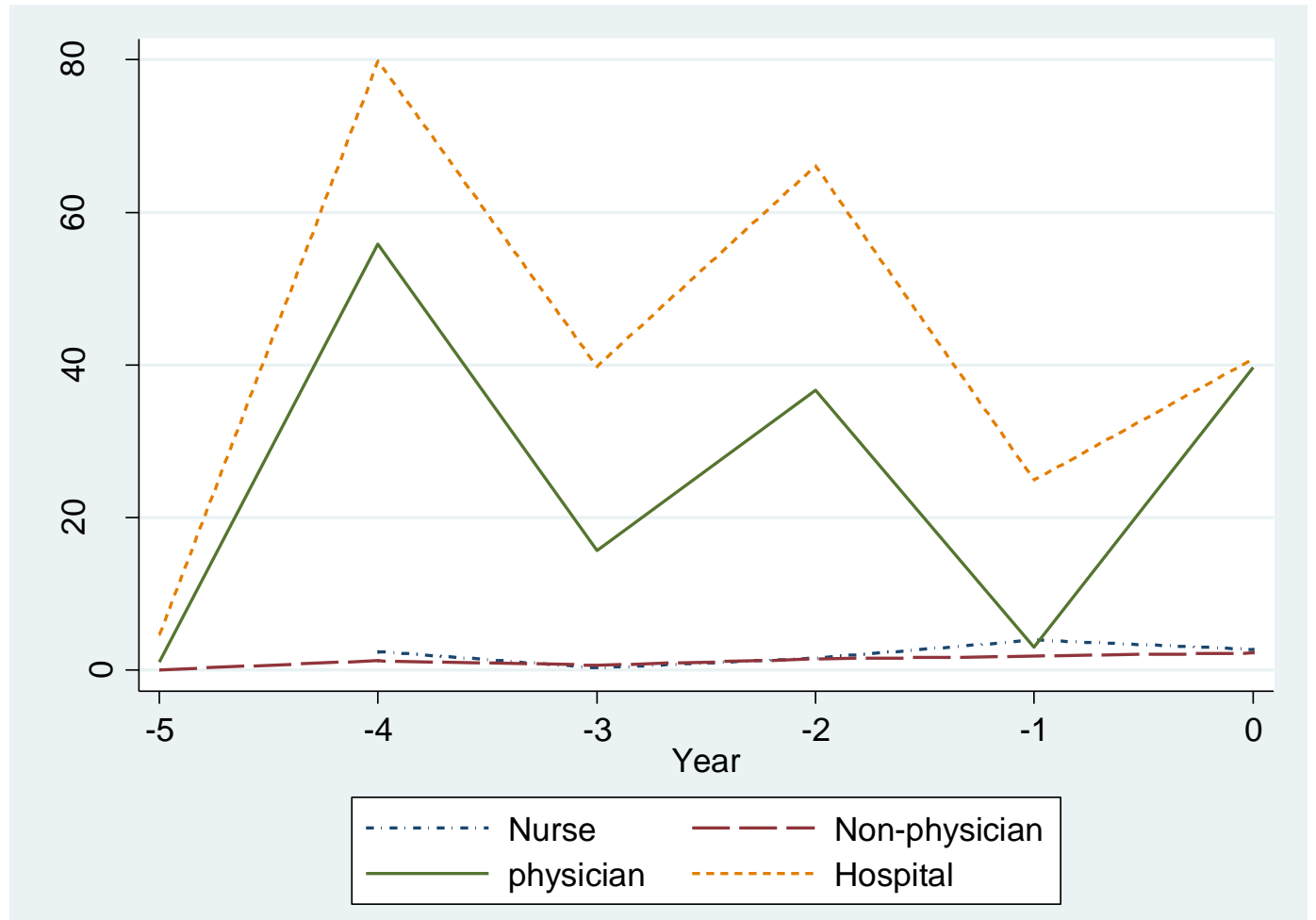

Note: A legal change occurs at zero, and this figure reports the average clout of different groups in the five years preceding that change. Only states that actually experienced a change are included in this figure. 
Table A1: Linear Probability Model Results for NP Supervision Laws (Non-physician Spending Excluded)

\begin{tabular}{|c|c|c|c|c|c|c|}
\hline Variables & $\begin{array}{c}(1) \\
\text { I(NP Indep) }\end{array}$ & $\begin{array}{c}(2) \\
\text { I(NP Indep) }\end{array}$ & $\begin{array}{c}(3) \\
\text { I(NP Indep) }\end{array}$ & $\begin{array}{c}(4) \\
\text { I(Less Super) }\end{array}$ & $\begin{array}{c}(5) \\
\text { I(Less Super) }\end{array}$ & $\begin{array}{c}(6) \\
\text { I(Less Super) }\end{array}$ \\
\hline Log(Nurse clout) (2-year) & $\begin{array}{c}0.006 \\
(0.004)\end{array}$ & & & $\begin{array}{c}0.008 \\
(0.005)\end{array}$ & & \\
\hline Log(Physician clout) (2-year) & $\begin{array}{l}-0.026^{* *} \\
(0.012)\end{array}$ & & & $\begin{array}{l}-0.031 \\
(0.020)\end{array}$ & & \\
\hline $\log ($ Hospital clout) (2-year) & $\begin{array}{c}0.016 \\
(0.014)\end{array}$ & & & $\begin{array}{c}0.010 \\
(0.022)\end{array}$ & & \\
\hline Log(Nurse clout) (3-year) & & $\begin{array}{c}0.010^{*} \\
(0.005)\end{array}$ & & & $\begin{array}{c}0.018^{*} \\
(0.009)\end{array}$ & \\
\hline Log(Physician clout) (3-year) & & $\begin{array}{l}-0.049 * * * \\
(0.012)\end{array}$ & & & $\begin{array}{l}-0.051 * * \\
(0.022)\end{array}$ & \\
\hline $\log ($ Hospital clout) (3-year) & & $\begin{array}{l}0.032^{* *} \\
(0.013)\end{array}$ & & & $\begin{array}{c}0.017 \\
(0.025)\end{array}$ & \\
\hline Log(Nurse clout) (4-year) & & & $\begin{array}{c}0.012 \\
(0.007)\end{array}$ & & & $\begin{array}{c}0.023^{*} \\
(0.013)\end{array}$ \\
\hline Log(Physician clout) (4-year) & & & $\begin{array}{l}-0.096^{* * * *} \\
(0.035)\end{array}$ & & & $\begin{array}{l}-0.093 * * \\
(0.040)\end{array}$ \\
\hline $\log ($ Hospital clout) (4-year) & & & $\begin{array}{l}0.078 * * \\
(0.033)\end{array}$ & & & $\begin{array}{c}0.056 \\
(0.041)\end{array}$ \\
\hline Observations & 765 & 765 & 765 & 765 & 765 & 765 \\
\hline R-squared & 0.895 & 0.897 & 0.900 & 0.921 & 0.923 & 0.924 \\
\hline
\end{tabular}

Note: The dependent variable in the first three columns is an indicator for whether a state allowed independent NP practice in a given year. The dependent variable in the final three columns is an indicator that takes the value one if a state allowed NPs to practice independently or required physician supervision only when NPs prescribe medications. All specifications include state and year fixed effects. Other covariates include the percentage of the population covered by Medicaid, by Medicare, and by private insurance; the percentage of the population that identifies as black; the population density of the state; the median income of the state; and indicators for a democratic governor, democratic legislature, republican legislature, noneconomic damages cap, collateral source rule reform, and joint and several liability reform. Standard errors clustered at the state level are reported in parentheses.

$* * *$ significant at $1 \%$ level; $* *$ significant at $5 \%$ level; * significant at $10 \%$ level. 


\section{Table A2: Linear Probability Model Results for PA Supervision Laws (Nurse Spending Excluded)}

\begin{tabular}{|c|c|c|c|c|c|c|}
\hline Variables & $\begin{array}{c}(1) \\
\text { I(Remote) }\end{array}$ & $\begin{array}{c}(2) \\
\text { I(Remote) }\end{array}$ & $\begin{array}{c}\text { (3) } \\
\text { I(Remote) }\end{array}$ & $\begin{array}{c}\text { (4) } \\
\text { I(Less Super) }\end{array}$ & $\begin{array}{c}(5) \\
\text { I(Less Super) }\end{array}$ & $\begin{array}{c}\text { (6) } \\
\text { I(Less Super) }\end{array}$ \\
\hline Log(Non-physician clout) (2-year) & $\begin{array}{l}-0.005 \\
(0.007)\end{array}$ & & & $\begin{array}{l}-0.007 \\
(0.010)\end{array}$ & & \\
\hline Log(Physician clout) (2-year) & $\begin{array}{l}-0.048 * * * \\
(0.013)\end{array}$ & & & $\begin{array}{l}-0.053 * * * \\
(0.016)\end{array}$ & & \\
\hline $\log ($ Hospital clout) (2-year) & $\begin{array}{l}0.048 * * \\
(0.024)\end{array}$ & & & $\begin{array}{l}0.064^{* *} \\
(0.028)\end{array}$ & & \\
\hline Log(Non-physician clout) (3-year) & & $\begin{array}{l}-0.007 \\
(0.008)\end{array}$ & & & $\begin{array}{l}-0.015 \\
(0.010)\end{array}$ & \\
\hline Log(Physician clout) (3-year) & & $\begin{array}{l}-0.048 * * * \\
(0.016)\end{array}$ & & & $\begin{array}{l}-0.057 * * \\
(0.022)\end{array}$ & \\
\hline Log(Hospital clout) (3-year) & & $\begin{array}{c}0.052 \\
(0.031)\end{array}$ & & & $\begin{array}{c}0.083^{*} \\
(0.044)\end{array}$ & \\
\hline Log(Non-physician clout) (4-year) & & & $\begin{array}{l}-0.009 \\
(0.010)\end{array}$ & & & $\begin{array}{l}-0.023 \\
(0.014)\end{array}$ \\
\hline Log(Physician clout) (4-year) & & & $\begin{array}{l}-0.047 * * \\
(0.020)\end{array}$ & & & $\begin{array}{l}-0.061 * \\
(0.031)\end{array}$ \\
\hline Log(Hospital clout) (4-year) & & & $\begin{array}{c}0.056 \\
(0.037)\end{array}$ & & & $\begin{array}{c}0.099^{*} \\
(0.055)\end{array}$ \\
\hline Observations & 765 & 765 & 765 & 765 & 765 & 765 \\
\hline R-squared & 0.886 & 0.886 & 0.886 & 0.903 & 0.904 & 0.904 \\
\hline
\end{tabular}

Note: The dependent variable in the first three columns is an indicator for whether a state allowed PAs to practice remotely. The dependent variable in the last three columns is an indicator for whether PAs were allowed to practice either remotely or quasi-remotely. All specifications include state and year fixed effects. Other covariates include the percentage of the population covered by Medicaid, by Medicare, and by private insurance; the percentage of the population that identifies as black; the population density of the state; the median income of the state; and indicators for a democratic governor, democratic legislature, republican legislature, noneconomic damages cap, collateral source rule reform, and joint and several liability reform. Standard errors clustered at the state level are reported in parentheses.

$* * *$ significant at $1 \%$ level; $* *$ significant at $5 \%$ level; * significant at $10 \%$ level. 
Table A3: Full Linear Probability Model Results for NP Supervision Laws

\begin{tabular}{|c|c|c|c|c|c|c|}
\hline Variables & $\begin{array}{c}(1) \\
\text { I(NP Indep) }\end{array}$ & $\begin{array}{c}(2) \\
\text { I(NP Indep) }\end{array}$ & $\begin{array}{c}(3) \\
\text { I(NP Indep) }\end{array}$ & $\begin{array}{c}(4) \\
\text { I(Less Super) }\end{array}$ & $\begin{array}{c}\text { (5) } \\
\text { I(Less Super) }\end{array}$ & $\begin{array}{c}(6) \\
\text { I(Less Super) } \\
\end{array}$ \\
\hline $\begin{array}{l}\text { Log(Nurse clout) } \\
(2 \text {-year) }\end{array}$ & $\begin{array}{c}0.006 \\
(0.004)\end{array}$ & & & $\begin{array}{l}0.008^{*} \\
(0.004)\end{array}$ & & \\
\hline $\begin{array}{l}\log (\text { Non-physician } \\
\text { clout) }(2 \text {-year) }\end{array}$ & $\begin{array}{c}0.002 \\
(0.004)\end{array}$ & & & $\begin{array}{c}0.003 \\
(0.009)\end{array}$ & & \\
\hline $\begin{array}{l}\text { Log }(\text { Physician } \\
\text { clout) (2-year) }\end{array}$ & $\begin{array}{l}-0.026 * * \\
(0.011)\end{array}$ & & & $\begin{array}{l}-0.030 \\
(0.018)\end{array}$ & & \\
\hline $\begin{array}{l}\text { Log(Hospital clout }) \\
\text { (2-year) }\end{array}$ & $\begin{array}{c}0.014 \\
(0.013)\end{array}$ & & & $\begin{array}{c}0.007 \\
(0.020)\end{array}$ & & \\
\hline $\begin{array}{l}\text { Log(Nurse clout) } \\
\text { (3-year) }\end{array}$ & & $\begin{array}{l}0.010^{*} \\
(0.005)\end{array}$ & & & $\begin{array}{l}0.017^{*} \\
(0.009)\end{array}$ & \\
\hline $\begin{array}{l}\log (\text { Non-physician } \\
\text { clout) (3-year) }\end{array}$ & & $\begin{array}{c}0.003 \\
(0.005)\end{array}$ & & & $\begin{array}{c}0.005 \\
(0.009)\end{array}$ & \\
\hline $\begin{array}{l}\text { Log(Physician } \\
\text { clout) (3-year) }\end{array}$ & & $\begin{array}{l}-0.048^{* * *} \\
(0.012)\end{array}$ & & & $\begin{array}{l}-0.049 * * \\
(0.021)\end{array}$ & \\
\hline $\begin{array}{l}\text { Log(Hospital clout) } \\
\text { (3-year) }\end{array}$ & & $\begin{array}{l}0.029 * * \\
(0.014)\end{array}$ & & & $\begin{array}{c}0.012 \\
(0.027)\end{array}$ & \\
\hline $\begin{array}{l}\text { Log(Nurse clout) } \\
\text { (4-year) }\end{array}$ & & & $\begin{array}{l}0.012 * \\
(0.007)\end{array}$ & & & $\begin{array}{l}0.022^{*} \\
(0.013)\end{array}$ \\
\hline $\begin{array}{l}\log (\text { Non-physician } \\
\text { clout) (4-year) }\end{array}$ & & & $\begin{array}{c}0.000 \\
(0.005)\end{array}$ & & & $\begin{array}{c}0.004 \\
(0.010)\end{array}$ \\
\hline $\begin{array}{l}\text { Log(Physician } \\
\text { clout) (4-year) }\end{array}$ & & & $\begin{array}{l}-0.096 * * * \\
(0.035)\end{array}$ & & & $\begin{array}{l}-0.092 * * \\
(0.041)\end{array}$ \\
\hline $\begin{array}{l}\text { Log(Hospital clout) } \\
\text { (4-year) }\end{array}$ & & & $\begin{array}{l}0.078 * * \\
(0.035)\end{array}$ & & & $\begin{array}{c}0.052 \\
(0.045)\end{array}$ \\
\hline $\begin{array}{l}\text { Democratic } \\
\text { governor }\end{array}$ & $\begin{array}{r}0.051^{*} \\
(0.025)\end{array}$ & $\begin{array}{l}0.049 * \\
(0.025)\end{array}$ & $\begin{array}{l}0.050 * * \\
(0.024)\end{array}$ & $\begin{array}{l}0.071^{*} \\
(0.037)\end{array}$ & $\begin{array}{c}0.068^{*} \\
(0.036)\end{array}$ & $\begin{array}{c}0.068^{*} \\
(0.035)\end{array}$ \\
\hline $\begin{array}{l}\text { Democratic } \\
\text { legislature }\end{array}$ & $\begin{array}{c}0.032 \\
(0.037)\end{array}$ & $\begin{array}{c}0.033 \\
(0.037)\end{array}$ & $\begin{array}{c}0.035 \\
(0.037)\end{array}$ & $\begin{array}{c}0.017 \\
(0.055)\end{array}$ & $\begin{array}{c}0.020 \\
(0.054)\end{array}$ & $\begin{array}{c}0.022 \\
(0.054)\end{array}$ \\
\hline $\begin{array}{l}\text { Republican } \\
\text { legislature }\end{array}$ & $\begin{array}{l}-0.023 \\
(0.024)\end{array}$ & $\begin{array}{l}-0.023 \\
(0.024)\end{array}$ & $\begin{array}{l}-0.023 \\
(0.023)\end{array}$ & $\begin{array}{l}-0.049 \\
(0.033)\end{array}$ & $\begin{array}{l}-0.050 \\
(0.033)\end{array}$ & $\begin{array}{l}-0.050 \\
(0.033)\end{array}$ \\
\hline Log(income) & $\begin{array}{c}0.309 \\
(0.640)\end{array}$ & $\begin{array}{c}0.267 \\
(0.597)\end{array}$ & $\begin{array}{c}0.198 \\
(0.524)\end{array}$ & $\begin{array}{c}0.215 \\
(0.794)\end{array}$ & $\begin{array}{c}0.191 \\
(0.768)\end{array}$ & $\begin{array}{c}0.143 \\
(0.725)\end{array}$ \\
\hline Population density & -0.023 & 0.020 & 0.056 & 0.030 & 0.111 & 0.166 \\
\hline
\end{tabular}




\begin{tabular}{|c|c|c|c|c|c|c|}
\hline & $(0.094)$ & $(0.092)$ & $(0.088)$ & $(0.150)$ & $(0.165)$ & $(0.175)$ \\
\hline Percentage black & $\begin{array}{c}0.011 \\
(0.008)\end{array}$ & $\begin{array}{l}0.010 \\
(0.007)\end{array}$ & $\begin{array}{c}0.009 \\
(0.007)\end{array}$ & $\begin{array}{c}0.023 \\
(0.015)\end{array}$ & $\begin{array}{c}0.021 \\
(0.015)\end{array}$ & $\begin{array}{c}0.020 \\
(0.016)\end{array}$ \\
\hline $\begin{array}{l}\text { Percentage private } \\
\text { insurance }\end{array}$ & $\begin{array}{c}0.012^{*} \\
(0.006)\end{array}$ & $\begin{array}{c}0.012 * \\
(0.006)\end{array}$ & $\begin{array}{c}0.012^{*} \\
(0.006)\end{array}$ & $\begin{array}{l}0.023 * * \\
(0.009)\end{array}$ & $\begin{array}{l}0.023 * * \\
(0.009)\end{array}$ & $\begin{array}{l}0.022 * * \\
(0.008)\end{array}$ \\
\hline $\begin{array}{l}\text { Percentage } \\
\text { Medicaid }\end{array}$ & $\begin{array}{c}0.011 \\
(0.008)\end{array}$ & $\begin{array}{c}0.011 \\
(0.008)\end{array}$ & $\begin{array}{c}0.012 \\
(0.008)\end{array}$ & $\begin{array}{l}0.023^{* *} \\
(0.011)\end{array}$ & $\begin{array}{l}0.021^{*} \\
(0.011)\end{array}$ & $\begin{array}{l}0.022^{* * *} \\
(0.011)\end{array}$ \\
\hline $\begin{array}{l}\text { Percentage } \\
\text { Medicare }\end{array}$ & $\begin{array}{c}0.016 \\
(0.012)\end{array}$ & $\begin{array}{c}0.016 \\
(0.012)\end{array}$ & $\begin{array}{c}0.017 \\
(0.012)\end{array}$ & $\begin{array}{c}0.034 \\
(0.024)\end{array}$ & $\begin{array}{c}0.034 \\
(0.024)\end{array}$ & $\begin{array}{c}0.036 \\
(0.024)\end{array}$ \\
\hline $\begin{array}{l}\text { Noneconomic } \\
\text { damages cap }\end{array}$ & $\begin{array}{c}0.111 \\
(0.083)\end{array}$ & $\begin{array}{c}0.113 \\
(0.079)\end{array}$ & $\begin{array}{c}0.119 \\
(0.077)\end{array}$ & $\begin{array}{c}0.130 \\
(0.204)\end{array}$ & $\begin{array}{c}0.129 \\
(0.197)\end{array}$ & $\begin{array}{c}0.133 \\
(0.193)\end{array}$ \\
\hline $\begin{array}{l}\text { Collateral source } \\
\text { rule reform }\end{array}$ & $\begin{array}{l}-0.120^{*} \\
(0.063)\end{array}$ & $\begin{array}{l}-0.125^{*} \\
(0.062)\end{array}$ & $\begin{array}{l}-0.127 * * \\
(0.061)\end{array}$ & $\begin{array}{l}-0.172 \\
(0.136)\end{array}$ & $\begin{array}{l}-0.177 \\
(0.134)\end{array}$ & $\begin{array}{l}-0.179 \\
(0.132)\end{array}$ \\
\hline $\begin{array}{l}\text { Joint and several } \\
\text { reform }\end{array}$ & $\begin{array}{l}-0.031 \\
(0.055)\end{array}$ & $\begin{array}{l}-0.030 \\
(0.052)\end{array}$ & $\begin{array}{l}-0.034 \\
(0.050)\end{array}$ & $\begin{array}{l}-0.004 \\
(0.123)\end{array}$ & $\begin{array}{c}0.001 \\
(0.118)\end{array}$ & $\begin{array}{l}-0.001 \\
(0.117)\end{array}$ \\
\hline $\begin{array}{l}\text { Observations } \\
\text { R-squared }\end{array}$ & $\begin{array}{r}765 \\
0.895 \\
\end{array}$ & $\begin{array}{c}765 \\
0.897 \\
\end{array}$ & $\begin{array}{c}765 \\
0.900 \\
\end{array}$ & $\begin{array}{r}765 \\
0.921 \\
\end{array}$ & $\begin{array}{c}765 \\
0.923\end{array}$ & $\begin{array}{c}765 \\
0.924 \\
\end{array}$ \\
\hline
\end{tabular}

Note: The dependent variable in the first three columns is an indicator for whether a state allowed independent NP practice in a given year. The dependent variable in the final three columns is an indicator that takes the value one if a state allowed NPs to practice independently or required physician supervision only when NPs prescribe medications. All specifications include state and year fixed effects. Standard errors clustered at the state level are reported in parentheses.

$* * *$ significant at $1 \%$ level; $* *$ significant at $5 \%$ level; * significant at $10 \%$ level. 
Table A4: Full Linear Probability Model Results for PA Supervision Laws

\begin{tabular}{|c|c|c|c|c|c|c|}
\hline Variables & $\begin{array}{c}(1) \\
\mathrm{I}(\text { Remote })\end{array}$ & $\begin{array}{c}(2) \\
\text { I(Remote) }\end{array}$ & $\begin{array}{c}\text { (3) } \\
\text { I(Remote) }\end{array}$ & $\begin{array}{c}\text { (4) } \\
\text { I(Less Super) }\end{array}$ & $\begin{array}{c}\text { (5) } \\
\text { I(Less Super) }\end{array}$ & $\begin{array}{c}\text { (6) } \\
\text { I(Less Super) }\end{array}$ \\
\hline $\begin{array}{l}\log (\text { Non-physician } \\
\text { clout) }(2 \text {-year })\end{array}$ & $\begin{array}{l}-0.003 \\
(0.006)\end{array}$ & & & $\begin{array}{l}-0.006 \\
(0.008)\end{array}$ & & \\
\hline $\begin{array}{l}\text { Log(Nurse clout) (2- } \\
\text { year) }\end{array}$ & $\begin{array}{l}-0.010 \\
(0.009)\end{array}$ & & & $\begin{array}{l}-0.011 \\
(0.016)\end{array}$ & & \\
\hline $\begin{array}{l}\log (\text { Physician } \\
\text { clout) (2-year) }\end{array}$ & $\begin{array}{l}-0.053 * * * \\
(0.011)\end{array}$ & & & $\begin{array}{l}-0.058 * * * \\
(0.014)\end{array}$ & & \\
\hline $\begin{array}{l}\text { Log(Hospital clout }) \\
\text { (2-year) }\end{array}$ & $\begin{array}{l}0.059 * * * \\
(0.019)\end{array}$ & & & $\begin{array}{l}0.075^{* * *} \\
(0.026)\end{array}$ & & \\
\hline $\begin{array}{l}\log (\text { Non-physician } \\
\text { clout) (3-year) }\end{array}$ & & $\begin{array}{l}-0.006 \\
(0.007)\end{array}$ & & & $\begin{array}{l}-0.014 \\
(0.008)\end{array}$ & \\
\hline $\begin{array}{l}\log (\text { Nurse clout) (3- } \\
\text { year) }\end{array}$ & & $\begin{array}{l}-0.010 \\
(0.011)\end{array}$ & & & $\begin{array}{l}-0.012 \\
(0.019)\end{array}$ & \\
\hline $\begin{array}{l}\log (\text { Physician } \\
\text { clout) (3-year) }\end{array}$ & & $\begin{array}{l}-0.053 * * * \\
(0.014)\end{array}$ & & & $\begin{array}{l}-0.064 * * * \\
(0.021)\end{array}$ & \\
\hline $\begin{array}{l}\text { Log(Hospital clout) } \\
\text { (3-year) }\end{array}$ & & $\begin{array}{l}0.065^{* *} \\
(0.028)\end{array}$ & & & $\begin{array}{l}0.097 * * \\
(0.046)\end{array}$ & \\
\hline $\begin{array}{l}\log (\text { Non-physician } \\
\text { clout) (4-year) }\end{array}$ & & & $\begin{array}{l}-0.008 \\
(0.009)\end{array}$ & & & $\begin{array}{l}-0.021 \\
(0.013)\end{array}$ \\
\hline $\begin{array}{l}\log (\text { Nurse clout) (4- } \\
\text { year) }\end{array}$ & & & $\begin{array}{l}-0.009 \\
(0.012)\end{array}$ & & & $\begin{array}{l}-0.009 \\
(0.021)\end{array}$ \\
\hline $\begin{array}{l}\log (\text { Physician } \\
\text { clout) (4-year) }\end{array}$ & & & $\begin{array}{l}-0.054 * * * \\
(0.018)\end{array}$ & & & $\begin{array}{l}-0.068 * * \\
(0.028)\end{array}$ \\
\hline $\begin{array}{l}\log (\text { Hospital clout }) \\
\text { (4-year) }\end{array}$ & & & $\begin{array}{l}0.068 * * \\
(0.033)\end{array}$ & & & $\begin{array}{l}0.110^{*} \\
(0.056)\end{array}$ \\
\hline $\begin{array}{l}\text { Democratic } \\
\text { governor }\end{array}$ & $\begin{array}{c}0.037 \\
(0.027)\end{array}$ & $\begin{array}{c}0.037 \\
(0.027)\end{array}$ & $\begin{array}{c}0.037 \\
(0.027)\end{array}$ & $\begin{array}{c}0.072 \\
(0.051)\end{array}$ & $\begin{array}{c}0.074 \\
(0.050)\end{array}$ & $\begin{array}{c}0.076 \\
(0.050)\end{array}$ \\
\hline $\begin{array}{l}\text { Democratic } \\
\text { legislature }\end{array}$ & $\begin{array}{l}-0.031 \\
(0.025)\end{array}$ & $\begin{array}{l}-0.033 \\
(0.026)\end{array}$ & $\begin{array}{l}-0.033 \\
(0.027)\end{array}$ & $\begin{array}{l}-0.031 \\
(0.045)\end{array}$ & $\begin{array}{l}-0.032 \\
(0.047)\end{array}$ & $\begin{array}{l}-0.032 \\
(0.048)\end{array}$ \\
\hline $\begin{array}{l}\text { Republican } \\
\text { legislature }\end{array}$ & $\begin{array}{l}-0.026 \\
(0.030)\end{array}$ & $\begin{array}{l}-0.027 \\
(0.029)\end{array}$ & $\begin{array}{l}-0.029 \\
(0.029)\end{array}$ & $\begin{array}{l}-0.056 \\
(0.067)\end{array}$ & $\begin{array}{l}-0.057 \\
(0.066)\end{array}$ & $\begin{array}{l}-0.059 \\
(0.066)\end{array}$ \\
\hline Log(income) & $\begin{array}{c}0.445 \\
(0.523)\end{array}$ & $\begin{array}{c}0.407 \\
(0.532)\end{array}$ & $\begin{array}{c}0.411 \\
(0.541)\end{array}$ & $\begin{array}{c}0.138 \\
(0.717)\end{array}$ & $\begin{array}{c}0.042 \\
(0.721)\end{array}$ & $\begin{array}{c}0.011 \\
(0.732)\end{array}$ \\
\hline Population density & $0.601 * * *$ & $0.597 * * *$ & $0.594 * * *$ & $1.421 * * *$ & $1.419 * * *$ & $1.412 * * *$ \\
\hline
\end{tabular}




\begin{tabular}{|c|c|c|c|c|c|c|}
\hline & $(0.144)$ & $(0.151)$ & $(0.147)$ & (0.184) & (0.199) & $(0.205)$ \\
\hline Percentage black & $\begin{array}{c}0.009 \\
(0.011)\end{array}$ & $\begin{array}{c}0.009 \\
(0.012)\end{array}$ & $\begin{array}{c}0.009 \\
(0.012)\end{array}$ & $\begin{array}{c}0.007 \\
(0.020)\end{array}$ & $\begin{array}{c}0.007 \\
(0.020)\end{array}$ & $\begin{array}{c}0.007 \\
(0.020)\end{array}$ \\
\hline $\begin{array}{l}\text { Percentage private } \\
\text { insurance }\end{array}$ & $\begin{array}{c}0.001 \\
(0.007)\end{array}$ & $\begin{array}{c}0.002 \\
(0.007)\end{array}$ & $\begin{array}{c}0.002 \\
(0.007)\end{array}$ & $\begin{array}{l}-0.003 \\
(0.010)\end{array}$ & $\begin{array}{l}-0.003 \\
(0.010)\end{array}$ & $\begin{array}{l}-0.003 \\
(0.009)\end{array}$ \\
\hline $\begin{array}{l}\text { Percentage } \\
\text { Medicaid }\end{array}$ & $\begin{array}{c}0.001 \\
(0.006)\end{array}$ & $\begin{array}{c}0.001 \\
(0.006)\end{array}$ & $\begin{array}{c}0.001 \\
(0.007)\end{array}$ & $\begin{array}{l}-0.006 \\
(0.012)\end{array}$ & $\begin{array}{l}-0.005 \\
(0.011)\end{array}$ & $\begin{array}{l}-0.005 \\
(0.012)\end{array}$ \\
\hline $\begin{array}{l}\text { Percentage } \\
\text { Medicare }\end{array}$ & $\begin{array}{l}-0.025^{*} \\
(0.014)\end{array}$ & $\begin{array}{l}-0.026^{*} \\
(0.014)\end{array}$ & $\begin{array}{l}-0.026^{*} \\
(0.014)\end{array}$ & $\begin{array}{l}-0.026 \\
(0.020)\end{array}$ & $\begin{array}{l}-0.027 \\
(0.020)\end{array}$ & $\begin{array}{l}-0.027 \\
(0.020)\end{array}$ \\
\hline $\begin{array}{l}\text { Noneconomic } \\
\text { damages cap }\end{array}$ & $\begin{array}{l}-0.068 \\
(0.043)\end{array}$ & $\begin{array}{l}-0.071 \\
(0.044)\end{array}$ & $\begin{array}{l}-0.071 \\
(0.043)\end{array}$ & $\begin{array}{l}-0.066 \\
(0.116)\end{array}$ & $\begin{array}{l}-0.067 \\
(0.115)\end{array}$ & $\begin{array}{l}-0.068 \\
(0.114)\end{array}$ \\
\hline $\begin{array}{l}\text { Collateral source } \\
\text { rule reform }\end{array}$ & $\begin{array}{l}-0.099 * * \\
(0.045)\end{array}$ & $\begin{array}{l}-0.095 * * \\
(0.043)\end{array}$ & $\begin{array}{l}-0.092 * * \\
(0.044)\end{array}$ & $\begin{array}{l}-0.183 * * \\
(0.086)\end{array}$ & $\begin{array}{l}-0.176^{* *} \\
(0.085)\end{array}$ & $\begin{array}{l}-0.170^{*} \\
(0.086)\end{array}$ \\
\hline $\begin{array}{l}\text { Joint and several } \\
\text { reform }\end{array}$ & $\begin{array}{l}-0.013 \\
(0.049)\end{array}$ & $\begin{array}{l}-0.016 \\
(0.051)\end{array}$ & $\begin{array}{l}-0.019 \\
(0.052)\end{array}$ & $\begin{array}{l}-0.091 \\
(0.098)\end{array}$ & $\begin{array}{l}-0.102 \\
(0.102)\end{array}$ & $\begin{array}{l}-0.109 \\
(0.105)\end{array}$ \\
\hline Observations & 765 & 765 & 765 & 765 & 765 & 765 \\
\hline R-squared & 0.888 & 0.887 & 0.887 & 0.904 & 0.904 & 0.905 \\
\hline
\end{tabular}

Note: The dependent variable in the first three columns is an indicator for whether a state allowed PAs to practice remotely. The dependent variable in the last three columns is an indicator for whether PAs were allowed to practice either remotely or quasi-remotely. All specifications include state and year fixed effects. Standard errors clustered at the state level are reported in parentheses.

*** significant at $1 \%$ level; ** significant at $5 \%$ level; * significant at $10 \%$ level. 
Table A5: Linear Probability Model Results for NP Supervision Laws (Alternate Variable Definitions)

Panel A: PAs Opposed to NP Autonomy

\begin{tabular}{lcccccc}
\hline & $(1)$ & $(2)$ & $(3)$ & $(4)$ & $(5)$ & $(6)$ \\
& I(NP & I(NP & I(NP & I(Less & I(Less & $\begin{array}{c}\text { I(Less } \\
\text { Variables }\end{array}$ \\
Indep) & Indep) & Indep) & Super) & Super) & Super) \\
\hline Nurse Proportion (2-year) & $0.238^{*}$ & & & & & \\
& $(0.126)$ & & & $0.483^{* *}$ & & \\
Nurse Proportion (3-year) & & $0.408^{* *}$ & & $(0.208)$ & & \\
& & $(0.190)$ & & & $0.761^{* *}$ & \\
Nurse Proportion (4-year) & & & $0.594^{*}$ & & $(0.287)$ & \\
& & & $(0.308)$ & & & $0.981^{* *}$ \\
& & & & & & \\
Observations & 757 & 760 & 760 & 757 & 760 & 760 \\
R-squared & 0.893 & 0.894 & 0.895 & 0.920 & 0.921 & 0.921 \\
\hline
\end{tabular}

Panel B: PAs in Favor of NP Autonomy

\begin{tabular}{|c|c|c|c|c|c|c|}
\hline Variables & $\begin{array}{c}(1) \\
\text { I(NP } \\
\text { Indep) }\end{array}$ & $\begin{array}{c}(2) \\
\text { I(NP } \\
\text { Indep) }\end{array}$ & $\begin{array}{c}(3) \\
\text { I(NP } \\
\text { Indep) }\end{array}$ & $\begin{array}{c}(4) \\
\text { I(Less } \\
\text { Super) }\end{array}$ & $\begin{array}{c}(5) \\
\text { I(Less } \\
\text { Super) }\end{array}$ & $\begin{array}{c}(6) \\
\text { I(Less } \\
\text { Super) }\end{array}$ \\
\hline Nurse Proportion (2-year) & $\begin{array}{c}0.314 \\
(0.207)\end{array}$ & & & $\begin{array}{c}0.515 \\
(0.346)\end{array}$ & & \\
\hline Nurse Proportion (3-year) & & $\begin{array}{c}0.430 * \\
(0.254)\end{array}$ & & & $\begin{array}{c}0.734 * \\
(0.430)\end{array}$ & \\
\hline Nurse Proportion (4-year) & & & $\begin{array}{c}0.530 \\
(0.325)\end{array}$ & & & $\begin{array}{c}0.858 \\
(0.531)\end{array}$ \\
\hline $\begin{array}{l}\text { Observations } \\
\text { R-squared }\end{array}$ & $\begin{array}{c}757 \\
0.894\end{array}$ & $\begin{array}{c}760 \\
0.895\end{array}$ & $\begin{array}{c}760 \\
0.895\end{array}$ & $\begin{array}{c}757 \\
0.920\end{array}$ & $\begin{array}{c}760 \\
0.921\end{array}$ & $\begin{array}{c}760 \\
0.921\end{array}$ \\
\hline
\end{tabular}

Note: In panel A, each nurse proportion variable is calculated assuming that non-physician groups oppose greater NP autonomy, so spending by these groups is included in the total spending but not in the amount of spending by groups favorable to increased NP autonomy. In Panel B, each variable is calculated assuming that non-physician groups favor greater NP autonomy, so spending by these groups is included in both total spending and spending by groups favorable to increased NP autonomy. The dependent variable in the first three columns is an indicator for whether a state allowed independent NP practice in a given year. The dependent variable in the final three columns is an indicator that takes the value one if a state allowed NPs to practice independently or required physician supervision only when NPs 
prescribe medications. All specifications include state and year fixed effects. Other covariates include the percentage of the population covered by Medicaid, by Medicare, and by private insurance; the percentage of the population that identifies as black; the population density of the state; the median income of the state; and indicators for a democratic governor, democratic legislature, republican legislature, noneconomic damages cap, collateral source rule reform, and joint and several liability reform. Standard errors clustered at the state level are reported in parentheses.

*** significant at $1 \%$ level; ** significant at $5 \%$ level; * significant at $10 \%$ level. 


\section{Table A6: Linear Probability Model Results for PA Supervision Laws (Alternate Variable Definitions)}

\begin{tabular}{|c|c|c|c|c|c|c|}
\hline Variables & $\begin{array}{c}(1) \\
\text { I(Remote })\end{array}$ & $\begin{array}{c}(2) \\
\text { I(Remote })\end{array}$ & $\begin{array}{c}(3) \\
\text { I(Remote) }\end{array}$ & $\begin{array}{c}(4) \\
\text { I(Less } \\
\text { Super) }\end{array}$ & $\begin{array}{c}\text { (5) } \\
\text { I(Less } \\
\text { Super) }\end{array}$ & $\begin{array}{c}(6) \\
\text { I(Less } \\
\text { Super) }\end{array}$ \\
\hline Non-physician Proportion (2-year) & $\begin{array}{c}0.276^{*} \\
(0.164)\end{array}$ & & & $\begin{array}{c}0.261 \\
(0.207)\end{array}$ & & \\
\hline Non-physician Proportion (3-year) & & $\begin{array}{c}0.469^{*} \\
(0.244)\end{array}$ & & & $\begin{array}{c}0.493 \\
(0.404)\end{array}$ & \\
\hline Non-physician Proportion (4-year) & & & $\begin{array}{c}0.496^{*} \\
(0.248)\end{array}$ & & & $\begin{array}{c}0.503 \\
(0.429)\end{array}$ \\
\hline Observations & 765 & 765 & 765 & 765 & 765 & 765 \\
\hline R-squared & 0.886 & 0.887 & 0.887 & 0.903 & 0.903 & 0.903 \\
\hline
\end{tabular}

Panel B: NPs in Favor of PA Autonomy

\begin{tabular}{|c|c|c|c|c|c|c|}
\hline Variables & $\begin{array}{c}(1) \\
\mathrm{I}(\text { Remote })\end{array}$ & $\begin{array}{c}(2) \\
\text { I(Remote) }\end{array}$ & $\begin{array}{c}(3) \\
\text { I(Remote })\end{array}$ & $\begin{array}{c}(4) \\
\text { I(Less } \\
\text { Super) }\end{array}$ & $\begin{array}{c}\text { (5) } \\
\text { I(Less } \\
\text { Super) }\end{array}$ & $\begin{array}{c}(6) \\
\text { I(Less } \\
\text { Super) }\end{array}$ \\
\hline Non-physician Proportion (2-year) & $\begin{array}{c}0.288^{*} \\
(0.156)\end{array}$ & & & $\begin{array}{c}0.334 \\
(0.206)\end{array}$ & & \\
\hline Non-physician Proportion (3-year) & & $\begin{array}{c}0.406^{*} \\
(0.211)\end{array}$ & & & $\begin{array}{c}0.502 \\
(0.353)\end{array}$ & \\
\hline Non-physician Proportion (4-year) & & & $\begin{array}{l}0.426^{* *} \\
(0.210)\end{array}$ & & & $\begin{array}{c}0.509 \\
(0.374)\end{array}$ \\
\hline Observations & 765 & 765 & 765 & 765 & 765 & 765 \\
\hline R-squared & 0.886 & 0.887 & 0.887 & 0.903 & 0.904 & 0.904 \\
\hline
\end{tabular}

Note: In panel A, each non-physician proportion variable is calculated assuming that nurse groups oppose greater

PA autonomy, so spending by these groups is included in the total spending but not in the amount of spending by groups favorable to increased PA autonomy. In Panel B, each variable is calculated assuming that nurse groups favor greater PA autonomy, so spending by these groups is included in both total spending and spending by groups favorable to increased PA autonomy. The dependent variable in the first three columns is an indicator for whether a state allowed PAs to practice remotely. The dependent variable in the last three columns is an indicator for whether PAs were allowed to practice either remotely or quasi-remotely. All specifications include state and year fixed effects. Other covariates include the percentage of the population covered by Medicaid, by Medicare, and by private 
insurance; the percentage of the population that identifies as black; the population density of the state; the median income of the state; and indicators for a democratic governor, democratic legislature, republican legislature, noneconomic damages cap, collateral source rule reform, and joint and several liability. Standard errors clustered at the state level are reported in parentheses.

*** significant at $1 \%$ level; ** significant at $5 \%$ level; * significant at $10 \%$ level. 
Table A7: Rank Ordered Logit Results for NP Supervision Laws

\begin{tabular}{|c|c|c|c|}
\hline Variables & $\begin{array}{c}\text { (1) } \\
\text { NP Law } \\
\text { Ranking }\end{array}$ & $\begin{array}{c}(2) \\
\text { NP Law } \\
\text { Ranking }\end{array}$ & $\begin{array}{c}(3) \\
\text { NP Law } \\
\text { Ranking } \\
\end{array}$ \\
\hline Log(Nurse clout) (2-year) & $\begin{array}{c}0.003 \\
(0.011)\end{array}$ & & \\
\hline $\log ($ Non-physician clout) (2-year) & $\begin{array}{l}-0.008 \\
(0.015)\end{array}$ & & \\
\hline $\log$ (Physician clout) (2-year) & $\begin{array}{l}-0.042 \\
(0.046)\end{array}$ & & \\
\hline Log(Hospital clout) (2-year) & $\begin{array}{c}0.013 \\
(0.052)\end{array}$ & & \\
\hline Log(Nurse clout) (3-year) & & $\begin{array}{c}0.018 \\
(0.016)\end{array}$ & \\
\hline Log(Non-physician clout) (3-year) & & $\begin{array}{l}-0.008 \\
(0.018)\end{array}$ & \\
\hline Log(Physician clout) (3-year) & & $\begin{array}{l}-0.090^{* * *} \\
(0.042)\end{array}$ & \\
\hline Log(Hospital clout) (3-year) & & $\begin{array}{c}0.026 \\
(0.057)\end{array}$ & \\
\hline Log(Nurse clout) (4-year) & & & $\begin{array}{c}0.021 \\
(0.019)\end{array}$ \\
\hline Log(Non-physician clout) (4-year) & & & $\begin{array}{l}-0.014 \\
(0.020)\end{array}$ \\
\hline Log(Physician clout) (4-year) & & & $\begin{array}{l}-0.323^{* * * *} \\
(0.044)\end{array}$ \\
\hline $\log ($ Hospital clout) (4-year) & & & $\begin{array}{l}0.256^{* * * *} \\
(0.062)\end{array}$ \\
\hline Observations & 765 & 765 & 765 \\
\hline
\end{tabular}

Note: The dependent variable in all specifications is a ranking of NP supervision laws from least restrictive to most restrictive. All specifications include state and year fixed effects. Other covariates include the percentage of the population covered by Medicaid, by Medicare, and by private insurance; the percentage of the population that identifies as black; the population density of the state; the median income of the state; and indicators for a democratic governor, democratic legislature, republican legislature. Robust standard errors are reported in parentheses. The reported coefficients are untransformed coefficients because calculating the marginal effects of the coefficients from rank ordered logit models is more complicated than the more familiar logit models. However, in unreported results, I 
calculate the probability of different laws being ranked first across different states, and the results are consistent with the linear probability model results reported in the main paper *** significant at $1 \%$ level; ** significant at $5 \%$ level; * significant at $10 \%$ level. 
Table A8: Rank Ordered Logit Results for PA Supervision Laws

\begin{tabular}{|c|c|c|c|}
\hline Variables & $\begin{array}{c}(1) \\
\text { PA Law } \\
\text { Ranking }\end{array}$ & $\begin{array}{c}(2) \\
\text { PA Law } \\
\text { Ranking }\end{array}$ & $\begin{array}{c}\text { (3) } \\
\text { PA Law } \\
\text { Ranking }\end{array}$ \\
\hline Log(Non-physician clout) (2-year) & $\begin{array}{l}-0.016 \\
(0.015)\end{array}$ & & \\
\hline Log(Nurse clout) (2-year) & $\begin{array}{l}-0.025 \\
(0.018)\end{array}$ & & \\
\hline Log(Physician clout) (2-year) & $\begin{array}{l}-0.137 * * * \\
(0.028)\end{array}$ & & \\
\hline $\log ($ Hospital clout) (2-year) & $\begin{array}{l}0.169 * * * \\
(0.038)\end{array}$ & & \\
\hline Log(Non-physician clout) (3-year) & & $\begin{array}{l}-0.022 \\
(0.018)\end{array}$ & \\
\hline Log(Nurse clout) (3-year) & & $\begin{array}{l}-0.032 \\
(0.021)\end{array}$ & \\
\hline $\log$ (Physician clout) (3-year) & & $\begin{array}{l}-0.133 * * * \\
(0.033)\end{array}$ & \\
\hline $\log ($ Hospital clout) (3-year) & & $\begin{array}{l}0.198^{* * * *} \\
(0.059)\end{array}$ & \\
\hline Log(Non-physician clout) (4-year) & & & $\begin{array}{l}-0.022 \\
(0.025)\end{array}$ \\
\hline Log(Nurse clout) (4-year) & & & $\begin{array}{l}-0.032 \\
(0.025)\end{array}$ \\
\hline $\log$ (Physician clout) (4-year) & & & $\begin{array}{l}-0.140 * * * \\
(0.044)\end{array}$ \\
\hline $\log ($ Hospital clout) (4-year) & & & $\begin{array}{l}0.214 * * * \\
(0.072)\end{array}$ \\
\hline Observations & 765 & 765 & 765 \\
\hline
\end{tabular}

Note: The dependent variable in all specifications is a ranking of PA supervision laws from least restrictive to most restrictive. All specifications include state and year fixed effects. Other covariates include the percentage of the population covered by Medicaid, by Medicare, and by private insurance; the percentage of the population that identifies as black; the population density of the state; the median income of the state; and indicators for a democratic governor, democratic legislature, republican legislature. Robust standard errors are reported in parentheses. The reported coefficients are untransformed coefficients because calculating the marginal effects of the coefficients from 
rank ordered logit models is more complicated than the more familiar logit models. However, in unreported results, I calculate the probability of different laws being ranked first across different states, and the results are consistent with the linear probability model results reported in the main paper.

$* * *$ significant at $1 \%$ level; ** significant at $5 \%$ level; * significant at $10 \%$ level. 


\section{Table A9: Linear Probability Model Results for NP Supervision Laws (Controls Excluded)}

\begin{tabular}{|c|c|c|c|c|c|c|}
\hline Variables & $\begin{array}{c}\text { (1) } \\
\text { I(NP Indep) }\end{array}$ & $\begin{array}{c}(2) \\
\text { I(NP Indep) }\end{array}$ & $\begin{array}{c}(3) \\
\text { I(NP Indep) }\end{array}$ & $\begin{array}{c}\text { (4) } \\
\text { I(Less Super) }\end{array}$ & $\begin{array}{c}\text { (5) } \\
\text { I(Less Super) }\end{array}$ & $\begin{array}{c}\text { (6) } \\
\text { I(Less Super) }\end{array}$ \\
\hline $\log ($ Nurse clout) (2-year) & $\begin{array}{c}0.006 \\
(0.004)\end{array}$ & & & $\begin{array}{c}0.009^{*} \\
(0.005)\end{array}$ & & \\
\hline Log(Non-physician clout) (2-year) & $\begin{array}{c}0.002 \\
(0.005)\end{array}$ & & & $\begin{array}{c}0.002 \\
(0.009)\end{array}$ & & \\
\hline Log(Physician clout) (2-year) & $\begin{array}{l}-0.031 * * * \\
(0.005)\end{array}$ & & & $\begin{array}{l}-0.034 * * * \\
(0.010)\end{array}$ & & \\
\hline $\log ($ Hospital clout) (2-year) & $\begin{array}{l}0.018^{* *} \\
(0.007)\end{array}$ & & & $\begin{array}{c}0.009 \\
(0.012)\end{array}$ & & \\
\hline Log(Nurse clout) (3-year) & & $\begin{array}{c}0.010^{*} \\
(0.005)\end{array}$ & & & $\begin{array}{c}0.018^{*} \\
(0.009)\end{array}$ & \\
\hline $\log$ (Non-physician clout) (3-year) & & $\begin{array}{c}0.002 \\
(0.005)\end{array}$ & & & $\begin{array}{c}0.004 \\
(0.009)\end{array}$ & \\
\hline Log(Physician clout) (3-year) & & $\begin{array}{l}-0.053 * * * \\
(0.015)\end{array}$ & & & $\begin{array}{l}-0.053 * * * \\
(0.017)\end{array}$ & \\
\hline $\log ($ Hospital clout) (3-year) & & $\begin{array}{c}0.034^{*} \\
(0.018)\end{array}$ & & & $\begin{array}{c}0.011 \\
(0.024)\end{array}$ & \\
\hline $\log$ (Nurse clout) (4-year) & & & $\begin{array}{c}0.011 \\
(0.007)\end{array}$ & & & $\begin{array}{l}0.022 * \\
(0.013)\end{array}$ \\
\hline $\log$ (Non-physician clout) (4-year) & & & $\begin{array}{c}0.001 \\
(0.006)\end{array}$ & & & $\begin{array}{c}0.005 \\
(0.010)\end{array}$ \\
\hline Log(Physician clout) (4-year) & & & $\begin{array}{l}-0.100 * * \\
(0.043)\end{array}$ & & & $\begin{array}{l}-0.095 * * \\
(0.043)\end{array}$ \\
\hline $\log ($ Hospital clout) (4-year) & & & $\begin{array}{c}0.080^{*} \\
(0.045)\end{array}$ & & & $\begin{array}{c}0.050 \\
(0.049)\end{array}$ \\
\hline $\begin{array}{l}\text { Observations } \\
\text { R-squared }\end{array}$ & $\begin{array}{c}765 \\
0.891\end{array}$ & $\begin{array}{c}765 \\
0.893 \\
\end{array}$ & $\begin{array}{c}765 \\
0.896\end{array}$ & $\begin{array}{c}765 \\
0.918 \\
\end{array}$ & $\begin{array}{c}765 \\
0.919 \\
\end{array}$ & $\begin{array}{c}765 \\
0.920\end{array}$ \\
\hline
\end{tabular}

Note: The dependent variable in the first three columns is an indicator for whether a state allowed independent NP practice in a given year. The dependent variable in the final three columns is an indicator that takes the value one if a state allowed NPs to practice independently or required physician supervision only when NPs prescribe medications. All specifications include state and year fixed effects. Standard errors clustered at the state level are reported in parentheses.

*** significant at $1 \%$ level; ** significant at $5 \%$ level; * significant at $10 \%$ level. 


\section{Table A10: Linear Probability Model Results for PA Supervision Laws (Controls}

\section{Excluded)}

\begin{tabular}{|c|c|c|c|c|c|c|}
\hline Variables & $\begin{array}{c}(1) \\
\text { I(Remote) }\end{array}$ & $\begin{array}{c}(2) \\
\mathrm{I}(\text { Remote })\end{array}$ & $\begin{array}{c}(3) \\
\text { I(Remote) }\end{array}$ & $\begin{array}{c}(4) \\
\text { I(Less Super) }\end{array}$ & $\begin{array}{c}\text { (5) } \\
\text { I(Less Super) }\end{array}$ & $\begin{array}{c}(6) \\
\text { I(Less Super) }\end{array}$ \\
\hline Log(Non-physician clout) (2-year) & $\begin{array}{l}-0.004 \\
(0.006)\end{array}$ & & & $\begin{array}{l}-0.006 \\
(0.009)\end{array}$ & & \\
\hline Log(Nurse clout) (2-year) & $\begin{array}{l}-0.010 \\
(0.009)\end{array}$ & & & $\begin{array}{l}-0.012 \\
(0.016)\end{array}$ & & \\
\hline Log(Physician clout) (2-year) & $\begin{array}{l}-0.064 * * * \\
(0.015)\end{array}$ & & & $\begin{array}{l}-0.065^{* * *} \\
(0.011)\end{array}$ & & \\
\hline $\log ($ Hospital clout) (2-year) & $\begin{array}{l}0.072 * * * \\
(0.024)\end{array}$ & & & $\begin{array}{l}0.083^{* * * *} \\
(0.030)\end{array}$ & & \\
\hline Log(Non-physician clout) (3-year) & & $\begin{array}{l}-0.007 \\
(0.007)\end{array}$ & & & $\begin{array}{l}-0.014 \\
(0.009)\end{array}$ & \\
\hline Log(Nurse clout) (3-year) & & $\begin{array}{l}-0.010 \\
(0.011)\end{array}$ & & & $\begin{array}{l}-0.012 \\
(0.019)\end{array}$ & \\
\hline Log(Physician clout) (3-year) & & $\begin{array}{l}-0.068 * * * \\
(0.016)\end{array}$ & & & $\begin{array}{l}-0.071 * * * \\
(0.016)\end{array}$ & \\
\hline $\log ($ Hospital clout) (3-year) & & $\begin{array}{l}0.083^{* *} \\
(0.032)\end{array}$ & & & $\begin{array}{l}0.106^{* *} \\
(0.048)\end{array}$ & \\
\hline Log(Non-physician clout) (4-year) & & & $\begin{array}{l}-0.010 \\
(0.010)\end{array}$ & & & $\begin{array}{l}-0.022 \\
(0.013)\end{array}$ \\
\hline $\log$ (Nurse clout) (4-year) & & & $\begin{array}{l}-0.008 \\
(0.011)\end{array}$ & & & $\begin{array}{l}-0.009 \\
(0.021)\end{array}$ \\
\hline Log(Physician clout) (4-year) & & & $\begin{array}{l}-0.073^{* * *} \\
(0.021)\end{array}$ & & & $\begin{array}{l}-0.076^{* * * *} \\
(0.021)\end{array}$ \\
\hline $\log ($ Hospital clout) (4-year) & & & $\begin{array}{l}0.092 * * \\
(0.038)\end{array}$ & & & $\begin{array}{l}0.120^{* *} \\
(0.056)\end{array}$ \\
\hline Observations & 765 & 765 & 765 & 765 & 765 & 765 \\
\hline R-squared & 0.884 & 0.883 & 0.883 & 0.903 & 0.903 & 0.903 \\
\hline
\end{tabular}

Note: The dependent variable in the first three columns is an indicator for whether a state allowed PAs to practice remotely. The dependent variable in the last three columns is an indicator for whether PAs were allowed to practice either remotely or quasi-remotely. All specifications include state and year fixed effects. Standard errors clustered at the state level are reported in parentheses.

*** significant at $1 \%$ level; $* *$ significant at $5 \%$ level; * significant at $10 \%$ level. 
Table A11: Reverse Causation Regression Results for NP Supervision Laws

\begin{tabular}{lccccc}
\hline & \multicolumn{2}{c}{ NP Independence } & & \multicolumn{2}{c}{ NP Less Supervision } \\
\cline { 2 - 3 } Variables & Coefficient & Std Err & & Coefficient & Std Err \\
\hline & -0.304 & $(1.011)$ & & -0.098 & $(0.743)$ \\
Log(Nurse clout) (2-year) & -1.144 & $(0.986)$ & & -0.392 & $(0.741)$ \\
Log(Nurse clout) (3-year) & -0.443 & $(0.631)$ & & 0.029 & $(0.512)$ \\
Log(Nurse clout) (4-year) & 0.879 & $(0.585)$ & & 0.573 & $(0.362)$ \\
Log(Non-physician clout) (2-year) & 0.986 & $(0.603)$ & & 0.492 & $(0.367)$ \\
Log(Non-physician clout) (3-year) & 0.759 & $(0.581)$ & & 0.363 & $(0.326)$ \\
Log(Non-physician clout) (4-year) & 0.158 & $(0.184)$ & & -0.031 & $(0.133)$ \\
Log(Physician clout) (2-year) & 0.202 & $(0.173)$ & & -0.017 & $(0.163)$ \\
Log(Physician clout) (3-year) & 0.280 & $(0.176)$ & & 0.023 & $(0.148)$ \\
Log(Non-physician clout) (4-year) & 0.148 & $(0.185)$ & & -0.014 & $(0.117)$ \\
Log(Hospital clout) (2-year) & 0.181 & $(0.167)$ & & 0.001 & $(0.130)$ \\
Log(Hospital clout) (3-year) & 0.238 & $(0.150)$ & & 0.031 & $(0.115)$ \\
Log(Hospital clout) (4-year) & & & & \\
\hline
\end{tabular}

Note: Each reported coefficient and associated standard error for the NP Independence and NP Less Supervision indicator variables is estimated in a separate OLS regression with the clout measure on the left as the dependent variable. The year measurement noted in parentheses following each variable refers to the number of years following a given year that are used in calculating the relevant clout measure. This notation is different than that used in other tables. All specifications include a full set of state and year fixed effects.

*** significant at $1 \%$ level; ** significant at $5 \%$ level; * significant at $10 \%$ level. 
Table A12: Reverse Causation Regression Results for PA Supervision Laws

\begin{tabular}{|c|c|c|c|c|}
\hline & \multicolumn{2}{|c|}{ Remote Practice } & \multicolumn{2}{|c|}{ PA Less Supervision } \\
\hline & Coefficient & Std Err & Coefficient & Std Err \\
\hline Log(Nurse clout) (2-year) & -0.429 & $(1.051)$ & -0.141 & $(0.589)$ \\
\hline Log(Nurse clout) (3-year) & -0.330 & $(0.918)$ & -0.134 & $(0.489)$ \\
\hline Log(Nurse clout) (4-year) & -0.076 & $(0.769)$ & -0.083 & $(0.367)$ \\
\hline Log(Non-physician clout) (2-year) & -0.237 & (1.314) & -0.087 & $(0.580)$ \\
\hline Log(Non-physician clout) (3-year) & -0.214 & $(1.106)$ & -0.076 & $(0.445)$ \\
\hline Log(Non-physician clout) (4-year) & -0.337 & $(0.916)$ & -0.188 & $(0.372)$ \\
\hline Log(Physician clout) (2-year) & -0.052 & $(0.719)$ & 0.244 & $(0.412)$ \\
\hline Log(Physician clout) (3-year) & -0.309 & $(0.532)$ & 0.024 & $(0.252)$ \\
\hline Log(Non-physician clout) (4-year) & -0.309 & $(0.407)$ & -0.033 & $(0.161)$ \\
\hline Log(Hospital clout) (2-year) & 0.252 & $(0.707)$ & 0.342 & $(0.404)$ \\
\hline Log(Hospital clout) (3-year) & 0.005 & $(0.506)$ & 0.127 & $(0.231)$ \\
\hline $\log ($ Hospital clout) (4-year) & -0.005 & $(0.356)$ & 0.058 & $(0.128)$ \\
\hline
\end{tabular}

Note: Each reported coefficient and associated standard error for the Remote Practice and PA Less Supervision indicator variables is estimated in a separate OLS regression with the clout measure on the left as the dependent variable. The year measurement noted in parentheses following each variable refers to the number of years following a given year that are used in calculating the relevant clout measure. This notation is different than that used in other tables. All specifications include a full set of state and year fixed effects.

*** significant at $1 \%$ level; ** significant at $5 \%$ level; * significant at $10 \%$ level. 
Table A13: Linear Probability Model Results for NP Supervision Laws (Corporate Ban)

\begin{tabular}{|c|c|c|c|c|c|c|}
\hline Variables & $\begin{array}{c}(1) \\
\text { I(NP Indep) }\end{array}$ & $\begin{array}{c}(2) \\
\text { I(NP Indep) }\end{array}$ & $\begin{array}{c}\text { (3) } \\
\text { I(NP Indep) }\end{array}$ & $\begin{array}{c}\text { (4) } \\
\text { I(Less Super) }\end{array}$ & $\begin{array}{c}\text { (5) } \\
\text { I(Less Super) }\end{array}$ & $\begin{array}{c}\text { (6) } \\
\text { I(Less Super) }\end{array}$ \\
\hline $\log$ (Nurse clout) (2-year) & $\begin{array}{c}0.006 \\
(0.004)\end{array}$ & & & $\begin{array}{c}0.008^{*} \\
(0.004)\end{array}$ & & \\
\hline Log(Non-physician clout) (2-year) & $\begin{array}{c}0.002 \\
(0.004)\end{array}$ & & & $\begin{array}{c}0.003 \\
(0.009)\end{array}$ & & \\
\hline Log(Physician clout) (2-year) & $\begin{array}{l}-0.026^{* *} \\
(0.011)\end{array}$ & & & $\begin{array}{l}-0.030 \\
(0.019)\end{array}$ & & \\
\hline $\log ($ Hospital clout $)$ (2-year) & $\begin{array}{c}0.014 \\
(0.013)\end{array}$ & & & $\begin{array}{c}0.007 \\
(0.021)\end{array}$ & & \\
\hline $\log$ (Nurse clout) (3-year) & & $\begin{array}{c}0.010^{*} \\
(0.005)\end{array}$ & & & $\begin{array}{c}0.018^{*} \\
(0.009)\end{array}$ & \\
\hline Log(Non-physician clout) (3-year) & & $\begin{array}{c}0.003 \\
(0.005)\end{array}$ & & & $\begin{array}{c}0.005 \\
(0.009)\end{array}$ & \\
\hline Log(Physician clout) (3-year) & & $\begin{array}{l}-0.048 * * * \\
(0.012)\end{array}$ & & & $\begin{array}{l}-0.049 * * \\
(0.021)\end{array}$ & \\
\hline $\log ($ Hospital clout) (3-year) & & $\begin{array}{l}0.029 * * \\
(0.014)\end{array}$ & & & $\begin{array}{c}0.011 \\
(0.027)\end{array}$ & \\
\hline $\log$ (Nurse clout) (4-year) & & & $\begin{array}{c}0.012^{*} \\
(0.007)\end{array}$ & & & $\begin{array}{c}0.023 * \\
(0.013)\end{array}$ \\
\hline Log(Non-physician clout) (4-year) & & & $\begin{array}{c}0.000 \\
(0.005)\end{array}$ & & & $\begin{array}{c}0.004 \\
(0.010)\end{array}$ \\
\hline Log(Physician clout) (4-year) & & & $\begin{array}{l}-0.096 * * * \\
(0.035)\end{array}$ & & & $\begin{array}{l}-0.092 * * \\
(0.040)\end{array}$ \\
\hline $\log ($ Hospital clout) (4-year) & & & $\begin{array}{c}0.078^{* *} \\
(0.035)\end{array}$ & & & $\begin{array}{c}0.051 \\
(0.045)\end{array}$ \\
\hline Observations & 765 & 765 & 765 & 765 & 765 & 765 \\
\hline R-squared & 0.895 & 0.897 & 0.901 & 0.921 & 0.923 & 0.924 \\
\hline
\end{tabular}

Note: The dependent variable in the first three columns is an indicator for whether a state allowed independent NP practice in a given year. The dependent variable in the final three columns is an indicator that takes the value one if a state allowed NPs to practice independently or required physician supervision only when NPs prescribe medications. All specifications include state and year fixed effects. Other covariates include an indicator for whether a state had passed a ban on corporate independent expenditures; the percentage of the population covered by Medicaid, by Medicare, and by private insurance; the percentage of the population that identifies as black; the population density of the state; the median income of the state; and indicators for a democratic governor, democratic legislature, republican legislature, noneconomic damages cap, collateral source rule reform, and joint and several liability reform. Standard errors clustered at the state level are reported in parentheses.

*** significant at $1 \%$ level; $* *$ significant at $5 \%$ level; * significant at $10 \%$ level. 
Table A14: Linear Probability Model Results for PA Supervision Laws (Corporate Ban)

\begin{tabular}{|c|c|c|c|c|c|c|}
\hline Variables & $\begin{array}{c}(1) \\
\text { I(Remote) }\end{array}$ & $\begin{array}{c}(2) \\
\text { I(Remote) }\end{array}$ & $\begin{array}{c}(3) \\
\text { I(Remote) }\end{array}$ & $\begin{array}{c}\text { (4) } \\
\text { I(Less Super) }\end{array}$ & $\begin{array}{c}\text { (5) } \\
\text { I(Less Super) } \\
\end{array}$ & $\begin{array}{c}\text { (6) } \\
\text { I(Less Super) }\end{array}$ \\
\hline Log(Non-physician clout) (2-year) & $\begin{array}{l}-0.005 \\
(0.005)\end{array}$ & & & $\begin{array}{l}-0.007 \\
(0.007)\end{array}$ & & \\
\hline Log(Nurse clout) (2-year) & $\begin{array}{l}-0.012 \\
(0.009)\end{array}$ & & & $\begin{array}{l}-0.014 \\
(0.014)\end{array}$ & & \\
\hline Log(Physician clout) (2-year) & $\begin{array}{l}-0.053 * * * \\
(0.012)\end{array}$ & & & $\begin{array}{l}-0.058 * * * \\
(0.013)\end{array}$ & & \\
\hline Log(Hospital clout) (2-year) & $\begin{array}{l}0.061 * * * \\
(0.020)\end{array}$ & & & $\begin{array}{l}0.078 * * * \\
(0.025)\end{array}$ & & \\
\hline Log(Non-physician clout) (3-year) & & $\begin{array}{l}-0.008 \\
(0.006)\end{array}$ & & & $\begin{array}{l}-0.016^{* *} \\
(0.008)\end{array}$ & \\
\hline Log(Nurse clout) (3-year) & & $\begin{array}{l}-0.014 \\
(0.009)\end{array}$ & & & $\begin{array}{l}-0.016 \\
(0.016)\end{array}$ & \\
\hline Log(Physician clout) (3-year) & & $\begin{array}{l}-0.054 * * * \\
(0.014)\end{array}$ & & & $\begin{array}{l}-0.064 * * * \\
(0.019)\end{array}$ & \\
\hline Log(Hospital clout) (3-year) & & $\begin{array}{l}0.069 * * \\
(0.029)\end{array}$ & & & $\begin{array}{l}0.103 * * \\
(0.045)\end{array}$ & \\
\hline Log(Non-physician clout) (4-year) & & & $\begin{array}{l}-0.009 \\
(0.009)\end{array}$ & & & $\begin{array}{l}-0.023^{*} \\
(0.013)\end{array}$ \\
\hline Log(Nurse clout) (4-year) & & & $\begin{array}{l}-0.014 \\
(0.010)\end{array}$ & & & $\begin{array}{l}-0.015 \\
(0.018)\end{array}$ \\
\hline Log(Physician clout) (4-year) & & & $\begin{array}{c}-0.054^{* * * *} \\
(0.018)\end{array}$ & & & $\begin{array}{l}-0.068^{* *} \\
(0.026)\end{array}$ \\
\hline Log(Hospital clout) (4-year) & & & $\begin{array}{l}0.074 * * \\
(0.034)\end{array}$ & & & $\begin{array}{l}0.117 * * \\
(0.056)\end{array}$ \\
\hline Observations & 765 & 765 & 765 & 765 & 765 & 765 \\
\hline R-squared & 0.896 & 0.896 & 0.896 & 0.908 & 0.909 & 0.909 \\
\hline
\end{tabular}

Note: The dependent variable in the first three columns is an indicator for whether a state allowed PAs to practice remotely. The dependent variable in the last three columns is an indicator for whether PAs were allowed to practice either remotely or quasi-remotely. All specifications include state and year fixed effects. Other covariates include an indicator for whether a state had passed a ban on corporate independent expenditures; the percentage of the population covered by Medicaid, by Medicare, and by private insurance; the percentage of the population that identifies as black; the population density of the state; the median income of the state; and indicators for a democratic governor, democratic legislature, republican legislature, noneconomic damages cap, collateral source rule reform, and joint and several liability reform. Standard errors clustered at the state level are reported in parentheses.

*** significant at $1 \%$ level; ** significant at $5 \%$ level; * significant at $10 \%$ level. 
Table A15: Identified Sets for Primary NP Supervision Law Results

\begin{tabular}{|c|c|c|c|c|}
\hline \multirow{2}{*}{ Variables } & \multicolumn{2}{|c|}{ NP Independence } & \multicolumn{2}{|c|}{ NP Less Supervision } \\
\hline & $\begin{array}{l}\text { Lower } \\
\text { Bound }\end{array}$ & $\begin{array}{l}\text { Upper } \\
\text { Bound }\end{array}$ & $\begin{array}{l}\text { Lower } \\
\text { Bound }\end{array}$ & $\begin{array}{l}\text { Upper } \\
\text { Bound }\end{array}$ \\
\hline $\log$ (Nurse clout) (2-year) & -0.004 & 0.006 & 0.005 & 0.008 \\
\hline Log(Non-physician clout) (2-year) & 0.002 & 0.003 & 0.003 & 0.005 \\
\hline Log(Physician clout) (2-year) & -0.026 & -0.015 & -0.031 & -0.030 \\
\hline Log(Hospital clout) (2-year) & 0.014 & 0.177 & 0.007 & 0.167 \\
\hline Log(Nurse clout) (3-year) & 0.003 & 0.010 & 0.010 & 0.017 \\
\hline Log(Non-physician clout) (3-year) & 0.002 & 0.003 & 0.005 & 0.006 \\
\hline Log(Physician clout) (3-year) & -0.048 & -0.047 & -0.064 & -0.049 \\
\hline Log(Hospital clout) (3-year) & 0.029 & 0.304 & 0.012 & 0.270 \\
\hline Log(Nurse clout) (4-year) & 0.010 & 0.012 & 0.022 & 0.024 \\
\hline $\log$ (Non-physician clout) (4-year) & -0.004 & 0.001 & -0.001 & 0.004 \\
\hline Log(Physician clout) (4-year) & -0.119 & -0.096 & -0.125 & -0.092 \\
\hline Log(Hospital clout) (4-year) & 0.078 & 0.488 & 0.456 & 0.052 \\
\hline
\end{tabular}

Note: The reported upper and lower bounds for each identified set are based on the specifications reported in Table 3.

Each identified set is calculated consistent with Oster (2016), and this calculation assumes that the amount of selection on the observed and unobserved variables is the same. 
Table A16: Identified Sets for Primary PA Supervision Law Results

\begin{tabular}{|c|c|c|c|c|}
\hline & \multicolumn{2}{|c|}{ Remote Practice } & \multicolumn{2}{|c|}{ PA Less Supervision } \\
\hline & Upper & Lower & Upper & Lower \\
\hline & Bound & Bound & Bound & Bound \\
\hline Log(Non-physician clout) (2-year) & -0.003 & -0.002 & -0.006 & -0.001 \\
\hline Log(Nurse clout) (2-year) & -0.010 & 0.013 & -0.011 & 0.024 \\
\hline Log(Physician clout) (2-year) & -0.053 & -0.044 & -0.100 & -0.058 \\
\hline Log(Hospital clout) (2-year) & 0.059 & 0.245 & 0.075 & 0.221 \\
\hline Log(Non-physician clout) (3-year) & -0.006 & -0.003 & -0.014 & -0.009 \\
\hline Log(Nurse clout) (3-year) & -0.010 & 0.019 & -0.012 & 0.032 \\
\hline Log(Physician clout) (3-year) & -0.053 & -0.036 & -0.113 & -0.064 \\
\hline Log(Hospital clout) (3-year) & 0.065 & 0.254 & 0.097 & 0.255 \\
\hline Log(Non-physician clout) (4-year) & -0.008 & 0.008 & -0.021 & -0.002 \\
\hline $\log ($ Nurse clout) (4-year) & -0.009 & 0.020 & -0.009 & 0.037 \\
\hline Log(Physician clout) (4-year) & -0.054 & -0.028 & -0.128 & -0.068 \\
\hline Log(Hospital clout) (4-year) & 0.068 & 0.259 & 0.110 & 0.277 \\
\hline
\end{tabular}

Note: The reported upper and lower bounds for each identified set are based on the specifications reported in Table 4.

Each identified set is calculated consistent with Oster (2016), and this calculation assumes that the amount of selection on the observed and unobserved variables is the same. 
Table A17: Group Size and Political Clout

\begin{tabular}{lccc}
\hline & $(1)$ & $(2)$ & $(3)$ \\
Variables & $\log ($ MD clout $)$ & $\log ($ nurse clout $)$ & $\log$ (non-physician clout) \\
\hline $\begin{array}{l}\text { Physicians as Percentage } \\
\text { of Population }\end{array}$ & 30.746 & & \\
& $(68.599)$ & & \\
Nurses as Percentage & & & \\
of Population & & & \\
& & & 113.287 \\
Non-physicians as & & & $(934.168)$ \\
Percentage of Population & & & \\
& 765 & 765 & 765 \\
& 0.629 & 0.535 & 0.602 \\
Observations & & & \\
R-squared & & & \\
\hline
\end{tabular}

Note: The dependent variable in all specifications is reported at the top of each column. All specifications include state and year fixed effects. Standard errors clustered at the state level are reported in parentheses.

*** significant at $1 \%$ level; ** significant at $5 \%$ level; * significant at $10 \%$ level. 